Portland State University

PDXScholar

7-11-1974

\title{
A Comparison Between Sources of Student Anti- Hunting Sentiment and Wildlife Information Sources of a Sample of Oregon Adults
}

Ronald E. Shay

Portland State University

Follow this and additional works at: https://pdxscholar.library.pdx.edu/open_access_etds

Part of the Critical and Cultural Studies Commons

Let us know how access to this document benefits you.

Recommended Citation

Shay, Ronald E., "A Comparison Between Sources of Student Anti-Hunting Sentiment and Wildlife Information Sources of a Sample of Oregon Adults" (1974). Dissertations and Theses. Paper 2041. https://doi.org/10.15760/etd.2040

This Thesis is brought to you for free and open access. It has been accepted for inclusion in Dissertations and Theses by an authorized administrator of PDXScholar. Please contact us if we can make this document more accessible: pdxscholar@pdx.edu. 
AN ABSTRACT OF THE THESIS OF Ronald E. Shay for the Master of Science in Speech Communication presented July II, 1974.

Title: A Comparison Between Sources of Student AntiHunting Sentiment and Wildlife Information Sources of a Sample of Oregon Adults.

APPROVED BY MEMBERS OF THE THESIS COMMITTEE:
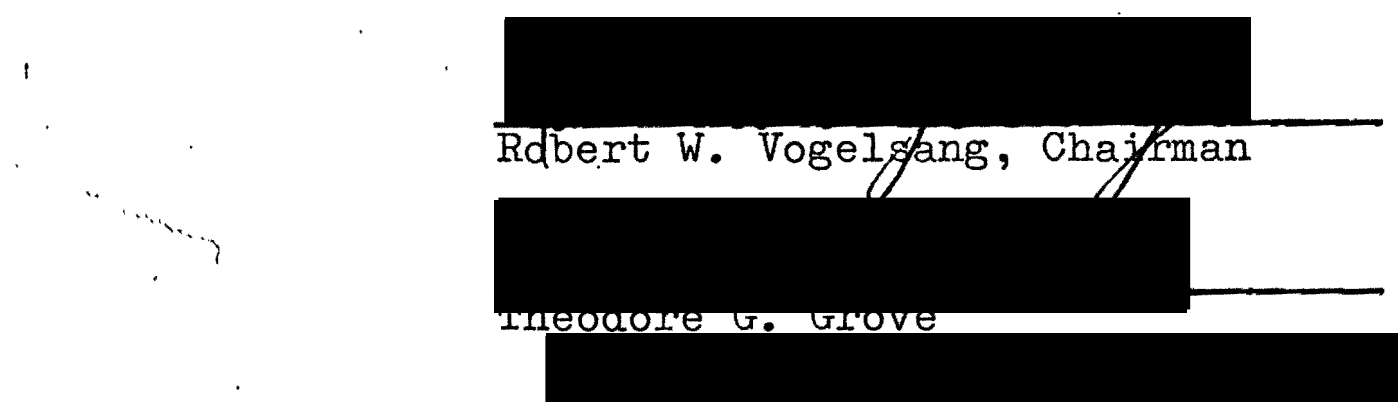

This study investigated the various sources of information utilized by a sample of the Oregon adult population to gain information and ideas about the wildlife resource. The results were compared to those of a study of college and university students and their sources of information that gave them anti-hunting attitudes.

The basic question posed was: What sources of information are most commonly utilized by a sample of Oregon's population in obtaining ideas and information concerning the wildlife resource and do the proportions of various 
sources utilized compare with those indicated by college students as sources of anti-hunting sentiments?

A sample of names of Oregon citizens was drawn from the telephone books of the state. One out of every 1000 names was drawn and a pre-tested questionnaire sent to them. This was the same questionnaire used to ascertain the sources of anti-hunting sentiments in students.

A return of 45 percent of the questionnaires was experienced. The data were analyzed with respect to the following hypothesis:

Hypothesis: There will be no significant difference in the proportions of information sources utilized with respect to general information about wildife by Oregon adults and acquisition of anti-hunting sentiments by a nationwide sample of college students.

The null hypothesis was rejected on the basis of the material gathered. The sample of Oregon citizens revealed a somewhat similar pattern of use of the mass media and individual sources of information, but there were significant variations. The adult citizens indicated a much higher use of the mass media. The relationship of the uses of various sources somewhat paralleled that of the students of the earlier study, however one notable exception occurred. As might be expected, teachers were much more influential on the students than on the adults. 
Additional questions asked of the subjects revealed less anti-hunting sentiment than in many portions of the United States and further hinted at sample bias in the direction of pro-hunting attitudes. 
A COMPARISON BETWEEN SOURCES OF STUDENT ANTI-HUNTING SENTIMENT AND WILDIIFE INFORMATION SOURCES

OF A SAMPIE OF OREGON ADUITS

by

RONALD E. SHAY

1

A thesis submitted in partial fulfillment of the requirements for the degree of

MASTER OF SCIENCE

- in

SPEECH COMINUNICATION

Portland State University

1974 
TO THE OFFICE OF GRADUATE STUDIES AND RESEARCH:

The members of the Committee approve the thesis of Ronald E. Shay présented. July II, 1974.

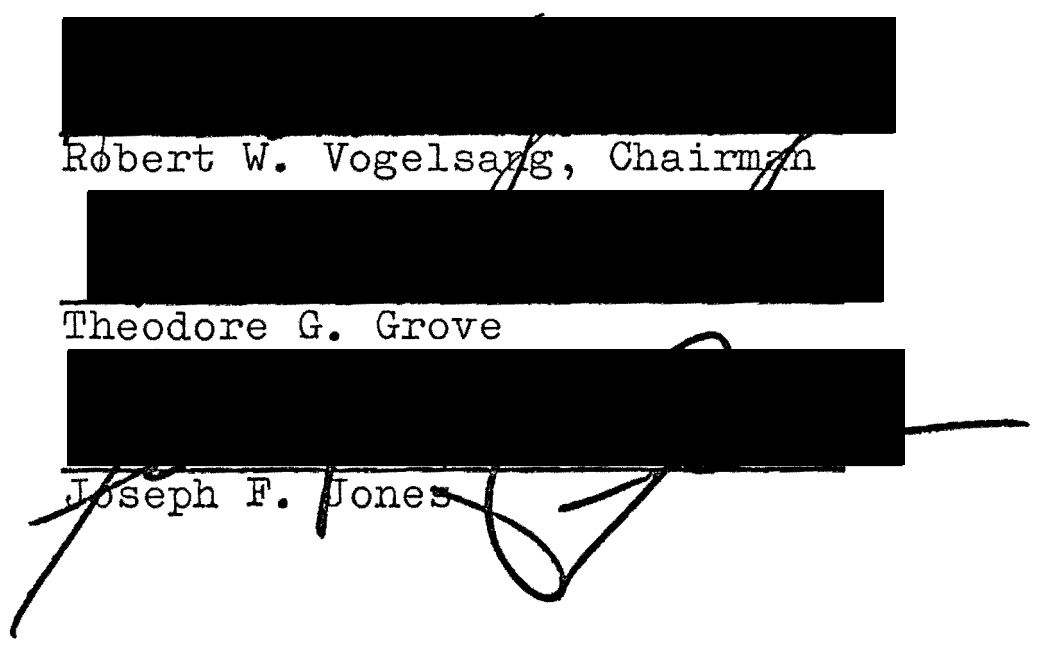

APPROVED:

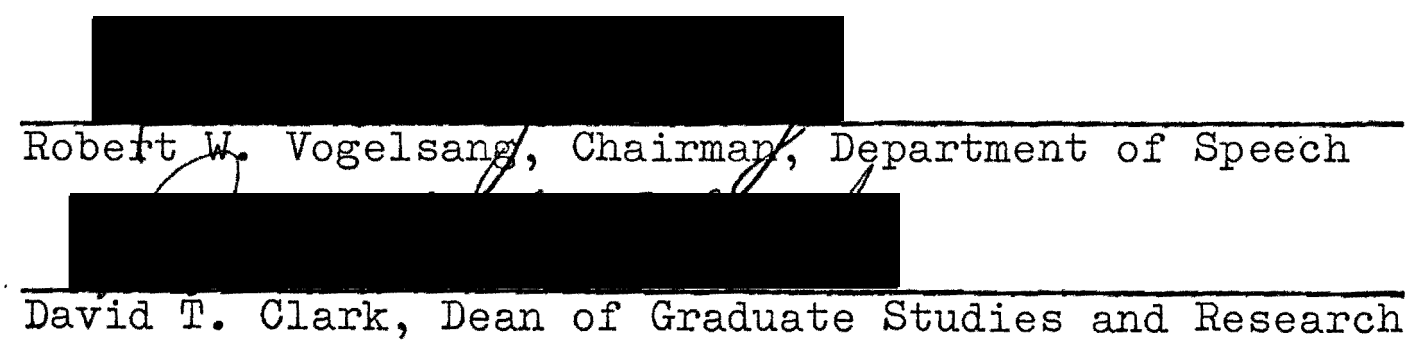




\section{ACKNOWLEDGMENTSS}

It seems appropriate to acknowledge those who have contributed to the accomplishment of this thesis. I am especially grateful to Dr. Harold Livingston of Oregon State University whose patience and encouragement have given me the necessary impetus to persist enough to. reach this point.

My gradualte committee chairman, Dr. Robert Vogelsang, has shown great understanding in helping choose this subject and his guidance has been most perceptive. Dr. Ted Grove aided in putting together the concepts and procedures for the study.

The cooperation of the Oregon Wildlife Commission in allowing time and use of facilities for gathering the data for the study is greatly appreciated. Most specifically, my thanks to Mr. Robert Holloway, Chief of the Information and Education Division for his tolerance, and Mr. Warren Aney, System Ecologist for his technical advice and assistance.

Many thanks are due to the cooperative Oregon citizens who generously took their time to fill out and return the rather lengthy questionnaire. Also to Dr. Dale. I. Shaw of Colorado for his permission to use his pre-tested, copyrighted questionnaire. 
Lastly, my gratitude to my wife Maryln and son Jeffrey for their assistance in accomplishing the many mechanical operations necessary for such an undertaking and their patience during my periods of exclusion during writing and preparation of this thesis. Also, my appreciation to my mother, Mrs. Vera Shay in preparation of the copy of the thesis. 
TABLE OF CONTENTS

PAGE

ACKNOWLEDGMENTS $\bullet \cdot \cdot \cdot \cdot \cdot \cdot \cdot \cdot \cdot \cdot \cdot \cdot \cdot \cdot \cdot \bullet$

IIST OF TABLES

vii

IIST OF FIGURES

ix

CHAPTER

I INTRODUCTION . . . . . . . . . . I

II REVIEW OF THE IITERATURE . . . . . . 7

III PROBLEM AND PROCEDURES . . . . . . 20

Genesis of the Problem . ... . . 20

Rationale for the Approach . . . . 21

Statement of the Problem . . . . 22

Hypothesis to be Tested . . . . 22

Definition of Terms ...... 23

Assumptions . . . . . . 23

Limitations . . . . . . . 24

Procedures . . . . . . . . 24

IV RESULTS • • . . • • • • . . : 34

General Results ....... 34

- The Respondents . . . . . 36

Sources of Information . . . . 38 
Number of Respondents who Hunt

$$
\text { and Fish and Attitudes }
$$

Toward Hunting . . . . . . 48

V SUMMARY AND CONCLUSIONS . . . . . . . 49

Summary of Results . . . . . . 49

Conclusions . . . . . . . . 51

Suggestions for Further Research . . . 54

BIBIIOGRAPHY • . . . . . . . . . . . . . 56

APPENDIX

A The Questionnaire . . . . . . . . 59

B Correspondence .. . . . . . . . 63

C Agès of Respondents . . . . . . . 66

D Specific Names of Programs and Other

Sources Listed by Oregon

Respondents........... 68

E Participation by Sex . . . . . . . 72

F Characteristics of Respondents Compared

to Size of Home Community . . . . . 74

G Hunting Attitudes . . . . . . . . 78 
IIST OF TABIES

TABI,E

PAGE

I Reasons for Non-Delivery of Questionnaires

as Indicated by Post Office . . . .

II Six of Respondents . . . . . . . . . .

III Age Data Summary . . . . . . . . .

IV Sources of Wildlife Information and Ideas

as Indicated by Number and Percentage

by Oregon Respondents . . . . . .

$\mathrm{V}$ Sources by Number and Percentage Which

Shaw's Students Reported Had Influenced

Them Against Hunting . . . . . . . 42

VI Sources Providing Information by Percentage

of Total Sources . . . . . . .

VII Specific Media Programs or Individuals Most

Frequently Mentioned as Sources of

Wildlife Information . . . . . . .

VIII Participation in Hunting and Fishing by

Sex •............ . . 73

IX Respondents by Size of Home Community . • . 75

$\mathrm{X}$ Respondents Who Hunt by Size of Home

Community by Number and Percent . . . 
XI Respondents Who Fish by Size of Home

Community by Number and Percent . . •

XII Attitudes Toward Hunting by Numbers and

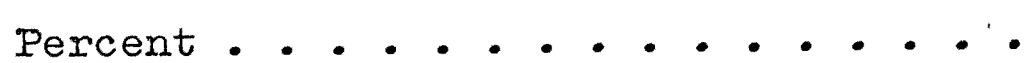

XIII Attitude Toward Hunting by Size of Home

Community . . . . . . . . . 80

XIV Attitude Toward Hunting by Age Groups . • $8 I$ 


\section{IIST OF FIGURES}

FIGURE

PAGE

1 Histogram Comparing Percentage of Shay

Respondents and Shaw Students

Indicating Use of Various Sources...

2 Histogram Comparing Percentage of Shay

Respondents and Shaw Students Responses

by Sources with Total Responses . . •

44 
CHAPTER I

INTRODUCTION

Communication between wildlife managers and the public has long been a concern. Almost from the beginning of attempts to manage the wildlife resource of Oregon, there have been statements that public understanding of the problems of the resource and its management is essential. In 1917 the Biennial Report of the Fish and Game Commission of Oregon stated:

But no matter how diligent and rigid may be the patrol service of the Game Department, no matter what efficiency may be reached in our hatchery work, no lasting conservation of our game can be obtained unless the game protection sentiment in our citizens goes in advance of the work of the hatcheries and the game wardens.

The building up of game protection sentiment, bringing about a realization on the part of our citizens of the vast benefit which our wild animal and fish life is to our state and to its citizens, is therefore an important feature of the work of our game department. 1

Similar statements may be found in many of the reports following the 1917 one cited. In 1956, Game Commissioner Don Mitcheil of Taft, Oregon reaffirmed the idea in an article in the Oregon State Game Commission Bulletin when he stated:

It is a common understanding in professional circles that wildlife management consists of 10 percent management of wild animals and 90 percent management of wild people. 2 
Until rather recent years however, little has been done to study precisely how people might be influenced to assist wildiffe managers in accomplishing their goals. Virtually all state:'s wildlife departments have had some type of information and education program in operation since early in the century, but the call for better public understanding continues, seemingly indicating the programs have been less than effective.

One of the nationally prominent figures in the field, Dr. Ira Gabrielson voiced virtually the same concern in 1941 when he said, "The most uncertain factor [in wildlife management] is not management itself, but public support for a suitable and effective program." 3

Clarence Schoenfeld writing of the Public Relations Aspects of Wildife Management further reiterated the problem stating, "King is one of a number of modern biologists who see that the real core of the [wildlife management] problem seems to be that the public does not understand our program and so is not ready to adapt it. " 4 This was in 1948.

Some of this lack of success can perhaps be attributed to the increasing urbanization of the populace of the United States and individual isolation from the land and consequent lack of understanding of the basic realities and biology of animal life and death. 
In recent years, this lack of general public understanding has taken on almost ominous overtones to the professional wildife biologist. Dasmann warns, "America's deer herds are being threatened today--threatened by the magnitude of their own numbers and by the growing legions of misinformed proponents of 'Bambi-ism'." 5

The "Environmental Movement" of the late 1960's and early 1970's recruited more misinformed individuals who had little feeling for or understanding of the biological needs of animals. The hunter became the target of many damning article's despite the fact that his monies were paying for most of the wildiffe conservation work being done in the United States. Actor, sportsman Robert Stack addressed the situation commenting:

Though sometimes attacked by an ill-informed public, sportsmen have done more than any other group to protect and preserve our great wildlife heritage. As the "age of environment" gains momentum, preservationists (anti-hunters) and wilderness enthusiasts seem to think that being against hunting is good conservation. This could not be further from the truth. Hunting, game management, conservation and environmental concern are partners. We must all work together for a cleaner, healthier, brighter world tomorrow. 6

In recent years, these sentiments have been re-echoed more regularly. Hendee and Schoenfeld said:

Public attitudes and actions are at the heart of defining and maintaining environmental quality in general and our wildlife resources in particular. Research is needed to help improve the ability of wildlife managers to produce a citizenry that is knowledgeable concerning problems that affect 
wildilfe, understand how to be effective in helping to solve these problems, and is motivated to work towards their solution.?

Larsen points out the lack of accurate coverage of science subjects as a possible cause of the problem.

It is apparent that the total coverage given to descriptions of progress or interpretations of the significance of progress in medicine, science and technology in representative daily newspapers falls far short of what could be considered adequate. Considering the critical importance of an informed electorate on matters of significance to modern civilization, greater coverage on these subjects and better interpretation in the light of broad global problems should be encouraged. 8

More specifically, in the field of wildlife management, Hooper points out:

A survey conducted in 1969 by the Gallup Organization, Inc., for the National Wildlife Federation, questioned citizens as to what action should be taken to preserve wildlife. The two most frequent answers were ( 1 ) provide stricter law enforcement and (2) reduce hunting.9

Further elaborating on the problem he states, "While professional wildlife biologists continue to learn more about consumptive wildlife management programs, the general public is understanding less . . . "lo

In his survey, Dale I. Shaw investigated the sources of information of college students as well as their attitudes concerning hunting. He found ". . of the reasons given for being against hunting, the largest response was in the category, 'Sport hunting endangers some species." "Il It is agreed by reputable biologists worldwide that such is not the case. Shaw's study further investigated the source 
of the anti-hunting attitudes in a selected group of college and university" students across the United States. It is the purpose of this study to try to determine if a sample of adult citizens of Oregon receive their Information and ideas about wildife from the same sources as Shaw's nationwide sample of students received antihunting ideas.

It is assumed that the findings of this study will point the way toward better informational programs designed to inform the public of the true problems of wildlife management and make it possible to solicit general public support in combating the actual threats to the wildlife populations. The results of the study will aid in a reassessment of state informational programs and possible adjustments of priorities. 
Notes (1917).

${ }^{1}$ Fish and Game Commission of Oregon, Biennial Report

2Don M. Mitchell, "Help Needed," Oregon State Game Commission Bulletin, 11, No: 12 (December, 1956), p. 6 .

${ }^{3}$ Clarence A. Schoenfeld, "Public Relations Aspects of Wildlife Management, "Journal of Wildlife Management, 21, No. I (1957), p. 70。

${ }^{4}$ Ibid.

5 William Dasmann, If Deer are to Survive (Harrisburg, Va.: Stackpole Books, 1971).

$6_{\text {Robert Stack, "Thanks to the Hunter," National }}$ Wildife, 9, No. 6 (Oct.-Nov., 1971), p. 17.

7 John C. Hendee and Clay Schoenfeld, Human Dimensions in Wildlife Programs (Rockville, Maryland: Mercury Press, 1973), p. 7 .

8 James A. Larsen, "Science, Communications, Society," The Journal of Environmental Management, 5, No. 1 (Fal1, 1973), pp. 21-22.

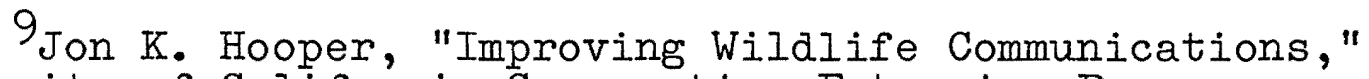
University of California Cooperative Extension Paper presented at the annual meeting of Western Section of The Wildlife Society, Monterey, Calif. 1-2 February 1974, p. I. ${ }^{10}$ Ibid. , p. 2.

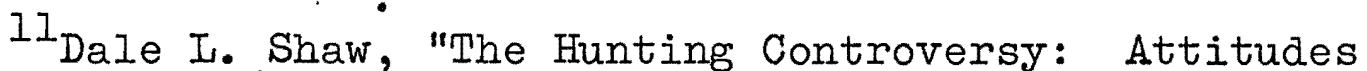
and Arguments" (Ph.D. dissertation, Colorado State University, 1973). 
CHAPTER II

\section{REVIEW OF THE IITERATURE}

This chapter will review literature that addresses itself to the impact of various media of information. In searching the literature on effects of mass media, it was discovered that little has been done that compares sources of information. Individual studies are numerous examining the influence of a single medium at a given time on a particular audience. However, little has been done recently to try to determine the relative impact of the various media on the thoughts and ideas of individuals.

Shaw's findings are some of the first that reveal specifically the sources of information concerning a natural resource subject. ${ }^{1}$

In 1971 Roper commented on the subject stating, "Not enough research has yet been done to be positive about how ideas are disseminated among Americans. "2

He continued later to indicate some of the problems:

This much we can assume to be correct: that the attitudes and beliefs of the general public are important to business management; that the general public is complex and heterogeneous; that within the public are many special interest groups who can be persuaded only when the communications used are in tune with their special interests and understanding; and that present efforts to communicate with the public as a whole are usually. inefficient and ineffective. 3 
A specialist in the field of natural resources public relations, Douglas Gilbert reiterated what has been said in the past.

- . managers of our natural resources must make every effort to keep knowledge of their publics at the same level or at a higher level as knowledge of natural resource management. 4

In discussing how this is attempted he points out:

The conservation magazine is the most popular method of communications used by a state conservation department. [1962 survey] Approximately 20 percent of the information and education budget is spent to make a regularly scheduled, departmental publication available. Both radio and television were regularly scheduled efforts but were far behind written, field and personal methods of contact in popularity. 5

It is likely that this may have changed in the past intervening years. However, based on this writer's observations, the magazine still is maintained as the mainstay of the state information and education budgets. Television activities have been accelerated in a number of states.

Gilbert gets to the heart of the problem saying: Effectiveness is very difficult to measure . . • State information and education personnel that attempted to rate the effectiveness of communications methods used listed them in the following order: field contacts and field trips; personal appearance programs including the use of slides and motion pictures, television programs; newspaper articles, magazines and pamphlets, and radio programs. 6

This makes it necessary to examine what is meant by effectiveness. It would appear the personnel were indicating their feelings concerning theix accomplishments in leaving the desired message with an identified group. Personal discussions with such information and education 
people indicate the major efforts are directed at presenting rather complex material to already interested audiences. As their choices would indicate this is best done by the personal contact methods and is difficult to accomplish through the mass media. Even more difficult is the task of getting such ideas to casually or uninterested individuals. Yet, it is in this type of cross section that the Shaw study found that anti-hunting attitudes were obtained largely from mass media.?

There is little doubt that the proliferation of television has had an effect on the choice and use of information sources of the current citizenry. Cushing and Lewert state:

- . the last major studies of college student's news media preferences were done so long ago--1962 - . that they cannot be relied upon to describe news media habits of the current college generation. 8

Further in their study it is pointed out, "Students chose magazines and 'people' as preferred news sources much more often than non-students did." 9 No such work was discovered concerning a cross section of the general public.

There is little doubt that the mass media can accomplish certain things in affecting the audience. Public relations workers have long used various media for accomplishing their tasks. Steinberg says:

There have been some doubts expressed as to the effectiveness of the mass media on public opinion. There can be little doubt that public relations can affect public opinion very significantly. . . public 
relations also utilizes one or more of the mass media as pipelines to public opinion. 10

There is some indication that the use of the various media and other sources of information such as parents and friends varies with different age groups. Davis found, - . that high school students are regular newspaper and magazine readers, and that the majority spend three hours per day listening to radio and three hours per day watching television. Radio was the student's primary news source because of its convenience. Findings indicated students use newspapers, radio, TV and magazines primarily for entertainment rather than news. 11

Thus it is indicated that certain groups do have preferences in their use of the media but it is not clear whether the media actually pass along information and ideas that form opinions. Much of the early research investigated this problem. Klapper says:

Communication research strongly indicates that persuasive mass communication is in general more likely to reinforce the existing opinions of its audience than it is to change such opinions. Minor attitude change appears to be a more likely

However, the mass media are not completely useless in putting forth ideas according to Klapper. He further states, "Mass communication is widely believed to be quite efficient in creating opinions among people who were not previously inclined one way or another on the issue in question." 13 As to the relationship of the various media he comments: The several media appear to be in themselves differentially effective as channels for persuasive communication, over and above the fact that they normally draw on somewhat different audiences. I4 
Reporting in a later work Klapper indicates mass media are able to accomplish information exchange under certain circumstances. He states, ". . mass communications generally serve to feed and to reinforce its audience's existing tastes, rather than to debase or improve them."15 Further he comments, ". . mass communications will change people if they are already predisposed to change."16 He additionally points out, ". . the media are quite effective in changing attitudes to which audience members are not particularly committed, a fact 'which explains much of media's effectiveness in advertising." 17

In considering mass media from the standpoint of communication theories, Katz reaffirms the comments of Klapper with, "Hence the generalization that the mass media typically reinforce people in their attitudes and practices, but rarely convert them." 18

The research would almost make the information and education worker consider the mass media a lost cause in his efforts to inform the public of wildife and its problems. The people who have misconceptions, it would appear, will not have them changed in this manner and those who are not interested or who don't have preconceived ideas probably won't receive the messages. There is an increasingly large group of the public who has little information concerning wildlife. Gans indicates there is some hope in getting to this group who may be influential in moving legislators and 
congressmen to pass laws affecting wildlife management. He states, "People are known to accept unquestioningly media content on subject matter of little interest to them. "19 Berelson and Steiner in summarizing some characteristics of human behavior point out, "People respond to persuasive communication in line with their predispositions, and they change or resist change accordingly. "20 However, these authors do not separate out the various media for comparison. Earlier they stated, "Neutrals on an issue or topic are unlikely to pay much attention to communications on that issue or topic, except when communications are highly available." 21 This might lead one to speculate that if the same message is put on one or all of the mass media available, often enough, it might be possible to get the idea across to some of the people, especially the uncommitted ones.

Other writers have continued to discuss the issue without coming up with any hard and fast answers. DeFleur points this out saying:

The issue of whether or not the media can convert people from one established form of behavior to another through altering their definition of the situation remains a thorny one. One school of thought on the matter denies that the media have much power to convert in well-established behavioral areas.22

Indicative of the lack of clear-cut information on the subject is the amount of conflicting writing that seems to be available. One need but search a bit to find almost any interpretation desired. Elson and Sheridan have more 
faith in the mass media stating:

In sum, the versatility, flexibility, and accessibility of the broadcast media cannot be overstated. Radios and television sets are found everywhere--in homes, cars, at beaches. Therefore it is more likely that a message, if repeated, will reach and be retained by the largest possible audience. Surveys conducted by our staff have shown extraordinarily high broadcaster acceptance of public relations programming. 23

Most writers have been rather general in their research or have addressed themselves to rather broad, vague subject matters when discussing whether people respond to mass media. It is apparent that people use the mass media. It also seems they do get some sort of message from it, but beyond that it is difficult to make any very definite statements about what is happening.

Persons interested in the wildlife resource may have different motives. Certain groups are interested simply from the standpoint that they feel it is necessary to care if birds, fish, and animals are treated properly by man the individual and mankind in general. The greatest group of interested persons however, is interested in the resource as a recreation provider. Non-consumptive users are growing in number as bird-watchers, photographers, and observers find challenge and intrigue in seeing wildlife.

The legendary concern for wildlife has been expressed by the hunter and angler and they continue to be the ones voicing the greatest concern and supplying the most funds for conservation programs. This group should be rather easily reached by the mass media because of their interest 
in the subject and their concern because of their recreational association with wildlife. Keel tends to verify this idea saying:

Once involved in a leisure activity, as one's interest in the topic increases so, too, will his knowledge of and involvement in it increase. Level of interest is the best predictor of variations in leisure-related communications behavior. Specifically, as knowledge and interest increase, so will use of the mass media for topic-related information, which will lead to greater knowledge and interest. Group membership does not necessarily increase with knowledge, interest or agtivity in a general sample of leisure participants. 2

Part of his findings could even indicate that the highly interested person might depend more and more on books and broadcast media for information.

This still leaves the dilemma of whether uninterested individuals can be reached with information on a subject that does not concern them either as a recreational pursuit or as an interest for some other reason. Opinion change does take place. According to Mills,

Today in the United States, . . both mass media and person to person discussion are important in changing public opinion. It is a question of which is the more important in different areas of opinion, at different times, and of just how the two, as forces causing opinion change, sometimes work together, and sometimes clash.25

The reinforcement role of the mass media is also again confirmed by Mills:

This self selection of audiences means that the chief influence of the mass media is not really to form or change opinion, but to reinforce a line of opinion already held, or at least already well known. 26 
He does indicate though, that certain groups might be more appropriate targets for any campaigns attempting change stating,". - opinion leaders are more exposed to the mass media of communications of all sorts than are the opinion followers." 27

Though it is difficult to determine whether mass media can truly change ideas once they are set, it does seem apparent it can plant ideas in minds where none preexist on a certain subject. As to exposure of the public to the mass media there is little doubt, therefore, it seems important to try to refine some of the ideas that exist concerning the effects of the media and the selectivity of the public in using the media. The audience is definitely there. Roberts summarizes it well stating:

One of the more striking features of contemporary society is the ubiquitous presence of the mass communications media.

Various studies of media use patterns in the U.S. have shown, for example, that by the end of the grade school years children average over three hours per day of television viewing, a figure which, with minor increases and decreases at various age levels, represents a good estimate of the amount of time adults spend with the television set; that use of all mass media combined accounts for over 50 percent of the leisure of adults; that by the time he graduates from high school a typical teen-ager has spent more time watching television than in the classroom. 28

He echoes previous authors however in commenting:

In short, the nature of the mass media, the mass audience, and the mass communication situation tends to minimize the possibility that mass mediated messages will cause a receiver to reorganize radically established beliefs, opinions or values. 29 
Conversely, writing further, Roberts gives information that makes it appear that idea implantation may be accomplished, saying:

- - because the media can and do make available large amounts of information about the world which we can never directly experience, mass communications are well suited to affect additions to our image of reality and to influence strongly how we structure parts of the environment about which we have little opportunity to acquire first hand knowledge. 30

It becomes apparent that there is a place for the use of the mass media in programs designed to inform and educate the public concerning the wildlife resource, or any other subject. It remains to be discovered just what messages, presented in what manner will most successfully do the job with the various audiences involved. In our modern society, the mass media appear to be the most reasonable choice to utilize to try to reach large groups of citizens who have little direct relationship with the land and little understanding of the biological realisms of life. Rivers and Schramm point out, "Most of us depend upon mass-communication products for a large majority of all the information and entertainment we receive during life."31

In the whole process of informing interested or uninterested publics about specific subject matter such as wildlife, basic principles must be applied. Rivers and Schramm summarize the problem stating:

The process of persuasion, . . consists of introducing information which leads the receiver to reappraise his perception of his environment, and through 
that to reappraise his needs and his ways of meeting them, or his social relationships, of his beliefs and attitudes.

The results of the various works indicate the strengths and weaknesses of the mass media and the relationship of various publics with varying degrees of interest in the subject matter being presented. To best utilize these findings it is necessary to further investigate sources of information utilized by publics, including both mass media and individual contact situations, and to try to determine which methods have been successful in transmitting information and implanting ideas. 
Notes

${ }^{1}$ Dale I. Shaw, "The Hunting Controversy: Attitudes and Arguments" (Ph.D. dissertation, Colorado State University, 1973).

${ }^{2}$ Elmo Roper, "Reaching the General Public," Public Relations Quarteriy, 16, No. 2 (1971), 'p. 22 .

3 Ibic. , p. 23.

${ }^{4}$ Douglas I. Gilbert, Natural Resources and Public Relations (Washington, D.C.: The Wildlife Society, 1971), p. 1 .

${ }^{5}$ Ibid., p. 108. ${ }^{6}$ Ibid. $7_{\text {Shaw, p. } 114 .}$

8illiam G. Cushing and James B. Lewert, "Has TV Altered Students' News Media Preferences?," Journalism Quarterly, 50, No. 1 (Spring, 1973), p. 139.

${ }^{9}$ Ibid., p. 140.

${ }^{10}$ Charles S. Steinberg, Mass Media and Communications

(New York: Hastings House, 1966), p. 401.

${ }^{11}$ Lina J. Davis, "Exposure To and Attitudes Toward the Mass Media of Students at Sam Houston High School"

(M.A. thesis,. North Texas State University, 1973).

12 Joseph T. Klapper, The Effects of Mass Communication (Glencoe, Illinois: The Free Press, 1960), p. 49.

13 Ibid. , p. 60: $\quad{ }^{14}$ Ibid., p. 129.

15 Joseph T. Klapper, "The Social Effects of Mass Communications," The Science of Human Communication (New York: Basic Books, Inc., 1963), p. 188 .

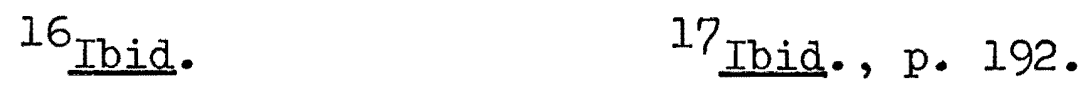

${ }^{18}$ Elihu Katz, "On Reopening the Question of Selectivity in Exposure to Mass Communications," Theories of Cognitive Consistency (Chicago: Rand McNally and Company, 1968), p. 161 .

${ }^{19}$ Herbert J. Gans, "The Critique of Mass Culture," Social Problems: A Modern Approach (New York: John Wiley and Sons, 1966), p. 55. 
20 Bernard Berelson and Gary A. Steiner, Human Behavior (New York: Harcourt, Brace and World, Inc., 1964), p. 540 .

\section{$21_{\text {Ibid. }}$, p. 531.}

22 Melvin I. DeFleur, Theories of Mass Communications

(New York: David McKay Co., 1970), p. 131 .

23 Robert E. Elson and William R. Sheridan, "Broadcast Media--The Neglected Tool of.P.R.," Public Relations Quarterly, 16, No. 3 (1971), p. 3 .

${ }^{24}$ Vernon A. Keel, "Leisure and the Mass Media: A Study of the Communications Behavior of Participants in a Major Area" (Ph.D. dissertation, University of Minnesota, 1973).

${ }^{25} \mathrm{C}$. Wright Mills, "Mass Media and Public Opinion," Mass Media and Mass Man, comp. Alan Casty (New York: Holt, Rinehart and Winston, 1973), p. 184.

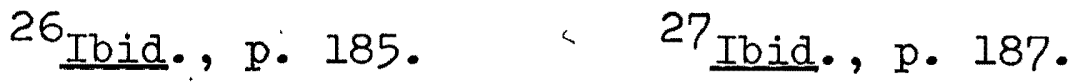

28 Donald F. Roberts, "The Nature of Communication Effects," The Process and Effects of Mass Communications (Urbana, Illinois: University of Illinois Press, 1971), p. 375.

29

Ibid., p. 377.

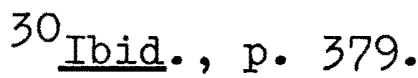

31 William Rivers and Wilbur Schramm, "The Impact of Mass Media," Mass Media and Mass Man, comp. Alan Casty (New York: Holt, Rinehart and Winston, 1973), p. 4. ${ }^{32}$ Ibid., p. 10. 


\section{CHAPTER III}

\section{PROBLEM AND PROCEDURES}

\section{GENESIS OF THE PROBLEM}

As was pointed out in the introduction, there has long been a recognized need for better communications with the public in the field of wildlife management. Shaw studied a specific type of information transfer with a specific audience. ${ }^{I}$ His sample of college students scattered throughout the United States revealed the sources oftheir anti-hunting sentiments.

It could be assumed that a sample of the general adult population of a given area received information from the same sources in a like proportion. However, such an assumption may be completely misleading and consequently do little to advance the art of communication about wildlife.

It was therefore decided to attempt to sample a more representative group of citizens in the State of Oregon to try to determine if their sources of information concerning the wildiffe resource were the same as those of the college students and in the same proportion of use. Such information could be useful in Oregon in planning communication programs to better inform the public of the problems of the 
wildlife resource and to maximize the efforts now being put forth.

\section{RATIONAIE FOR THE APPROACH}

It was recognized that to properly draw a random sample of the complete population of Oregon would be beyond economic and financial resources available. Since Shaw had sampled a group of younger individuals, it was felt that a broader sample which included citizens beyond college age would perhaps reveal data that could be contrasted with the college sample to suggest differences.

Records of the hunters and anglers licensed in the state were readily available, but it was felt that it was equally if not more important to draw some of the sample from the non-hunting and non-angling public. It is these groups who are casually interested or uninterested who may be important in/determining the future of wildlife management as a science.

Though Shaw focused on the source of the student's anti-hunting sentiment, it was felt that his sources could be compared with sources used by a broad sample of the public in obtaining any information concerning the wildlife resource. 


\section{STATEMENT OF THE PROBLEM}

Specifically the problems to be investigated were:

1. What sources of information are most commonly utilized by a sample of Oregon's adult population in obtaining ideas and information concerning the wildlife resource?

2. Are the proportions of various sources utilized comparable with those indicated by college students as sources of anti-hunting sentiment?

\section{HYPOTHESIS TO BE TESTED}

Iittle work has been done concerning the relative use of sources of information by the public. Many studies have examined the effects of single mass media inputs, but they have not tried to determine the relation between the uses of the various media and additional other sources.

Shaw measured the sources of anti-hunting sentiment in college and university students. His observations were limited to a group of students attending ten different colleges and universities.

The hypothesis to be tested by this study is:

Hypothesis: There will be no significant difference in the proportion of information sources utilized with respect to general information about wildlife by Oregon adults and acquisition of anti-hunting sentiments by a nationwide sample of college students. 
This hypothesis has been formulated by inspection of the data accumulated and compiled by Shaw in his study of student.s. Shaw's questionnaire was used in the present investigation to facilitate comparison of the two sets of responses.

\section{DEFINITION OF TERMS}

1. Respondent. An individual who completed and returned the questionnaires with enough material to be tallied in the final results. If single pieces of information'were omitted, remaining data were still entered in tabulations.

2. Sources. The various mass media and other originators of ideas and information listed on the questionnaire.

\section{ASSUMPTIONS}

Following is a clarification of the investigator's assumptions concerning this study.

It was necessary to assume the data collected from the sample of individuals questioned through the mail were as representative of their true feelings as those data collected by Shaw in a classroom situation.

The questionnaire was sent out on stationery of the Oregon Wildlife Commission to encourage as much return as possible. It is assumed that the use of stationery of an 
official governmental agency would not systematically bias the responses in a given direction and any bias would be worth it in increased returns.

\section{IIMITATIONS}

The nature of the sample drawn in this study automatically limits the generalizability of the results. The sample draw from telephone books obviously discriminates against those without telephones including recent immigrants to Oregon. It also discriminates against persons who may live in buildings where only one telephone number is listed and the calls all go through a switchboard of some type. The telephone book sample does not give fair representation to the non-head of households, the poor, females, and younger citizens in that few of them have telephones listed under their names.

Further limitations are in the scope of the sample. It represents only persons who have telephones listed in Oregon directories. Unlisted numbers are not considered.

Results of the study are limited in generalizability in that they reflect only the information voluntarily submitted by the 45 percent who returned the questionnaire.

\section{PROCEDURES}

\section{Sampling}

\footnotetext{
A mail questionnaire was. sent to a sample of persons listed in Oregon telephone directories.
} 
The sampling method was a Systemized Sample with a random start.

This method was selected because it was the most feasible way to draw as representative a sample of Oregon's population as possible and still keep the study feasible in terms of money and time.

Initially, after the decision was made to use the telephone books as a base, Clyde Williams of Pacific Northwest Bell Telephone Company was contacted. Mr. Williams supplied the following information: In Oregon as of March, 1974, Pacific Northwest Bell had 511,936 residential telephone hook-ups. As of the same date, the other 45 companies in the state had 199,246 residential hook-ups for a total of 711,182 . A sample of one individual per each 1000 names was decided upon as being feasible and yet large enough to reveal the necessary facts.

In trying to keep as much parallelism as possible in the survey, Mr. Dale Shaw was contacted to obtain permission to use his copyrighted questionnaire. Also, respondents were asked to indicate the size of their home community, their age, sex, whether they hunted and/or fished, and on a seven-point scale, their attitude toward hunting. This latter piece of information was added mainly to assess the validity of some claims that have been made concerning the public attitude toward sport hunting and also to add some additional relationships to the Shaw study. 
A complete set of telephone books for Oregon was available at the headquarters office of the Oregon Wildlife Commission. It was from these books that the sample was drawn.

Parten points out the limitations of this type of sample stating, ". . telephone subscribers are not a cross section of the population of any community. "2 These limitations are discussed in the section on limitations. Methodologically, Cochran, ${ }^{3} \mathrm{Kish}^{4}$ and Snedecor ${ }^{5}$ comment on the validity of the systemized sample with a random start. Cochran points out:

Systemized samples are convenient to draw and to execute... they may give poor precision when unsuspected periodicity is present. In light of these results, systematic sampling can safely be recommended in the following situations: 1-Where the ordering of the population is essentially random or contains at most a mild stratification. 6

Since there was no reason to suspect periodicity and it was felt that for the purpose of this study, the population was essentially random in the telephone books, the method was deemed appropriate.

Kish further comments on the problem of fluctuations and trends, but further allays any fears that problems might exist in the telephone books with, ". . such regularities are seldom present in population lists and the alert sampler can usually discover and avoid them. "7 $\mathrm{He}$ additionally states, "In most practical situations after investigating, we can dismiss the dangers both of a 
monotonic and of a periodic fluctuation coinciding with the selection interval." 8 A random start was used to minimize any such problems.

Another factor appears to preclude any trends occurring in the sampling of the telephone books. In Oregon, there are at least six different sizes of such books with different sizes of type and different numbers of columns on each page.

In such a method, Kish further points out:

The prime reason for using systematic sampling is that its application is easy, foolproof and flexible. Another advantage of systematic sampling is that it can easily yield a proportionate sample, if we take advantage of its even spread over the population ... Whatever stratification exists in the ordering $g^{f}$ the population list, the sample. will reflect it.

Snedecor further justifies our selection of the sampling method saying:

Systematic sampling has two advantages over simple random sampling. It is easier to draw, since only one random number is required and it distributes the sample more evenly over the listed population. For this reason systematic sampling often gives more accurate results than simple random sampling. 10

A number was selected from a table of random numbers. It was decided to take one name out of each 1000 in the books to give the desired sample of 711 names. At the beginning of each book, a count was made to start at the number. 951 which was the number selected from the table of random numbers. From this point on a measurment system was used to pick each 1000th name. This had to 
be adapted to several different type sizes in the various books, but a sample measurement made it relatively easy to determine how many names per inch were included in a particular type size. Books also varied from one to four columns of names per page. This was taken into account when establishing the sampling pattern.

At the beginning, it was decided to solve the problem of commercial telephone listings and blank spots on the page in the following manner. When the measure for the next name fell on such a line, the sampler moved one column at a time at the same level to the left until a valid name was obtained. The next time such an occurrence took place, the sampler moved directly across to the right and took the first usable name in a column in that direction. The alternate names were thus picked with the sampler alternately proceeding to the left and then to the right when invalid names were hit as part of the sequence.

The foregoing method was used rather than proceeding to the next name because it was felt by going to the next name it could load the sample with individuals who happened to be the first person listed under a certain letter of the alphabet and consequently were just below the blank spot where the break between letters occurs.

Sampling was done to make any error in numbers of names selected to provide a larger than necessary sample so if some names proved unusable it would be possible to go 
to the list rather than try to go back to the books to pick up additional names.

\section{The Questionnaire}

The basic questionnaire used was the same as that used by Shaw in his study of college students (see Appendix A).

Shaw states:

This questionnaire was developed by pretesting approximately 200 college students at Colorado State University with assistance from members of the Journalism, Psychology, and Statistics Departments at CSU and help from the author's [Shaw] graduate committee. Four revisions of the questionnaire were made during development.11

In addition to the basic questions concerning sources of ideas and information, a scale measuring attitude toward hunting was added. In addition, participants were asked their sex, age, size of community in which they live, whether they hunt or fish, and if they have. any other outdoor activities. The last item was not part of Shaw's survey.

All questionnaires were mailed out on April 30, 1974. Included with the questionnaire was a cover letter asking for cooperation (see Appendix B), a brief cover sheet asking demographic data and explaining what followed, and a postage paid return envelope. The outgoing mail was processed through a postage meter and the cover letter was a form letter. 
To increase the return, a reminder postcard was sent one week after the original questionnaire was sent (see Appendix B). Dillman in discussing ways to increase the return of mail questionnaires mentions:

Follow-ups included a one week postcard designed as a thank you . . . Anonymity was promised, but to cut follow-up expenses by contacting only nonrespondents and facilitate more printed communication, $\cdot \cdot$ an identification number was clearly placed on the cover. 12

The idea of an identifying number on the questionnaires was rejected by this investigator because it was felt it violated the promise of confidentiality. The follow-up postcard. was sent to all of the original names except those that had been proven unusable because they were returned by the post office department.

Non-deliverable questionnaires made up 7 percent or 51 of the 711 mailed. Table I indicates reasons why the non-deliverables fell into that class. 
TABLE I

REASONS FOR NON-DELIVERY OF QUESTIONNAIRES AS INDICATED BY POST OFFICE

Reason Marked on Envelope

Number

Undeliverable as addressed,

Unable to forward

Moved, Unable to forward ................ 13

No Such Street or Address .............., 10

Addressee Unknown ..................... 5

Not at, Address Listed $\ldots \ldots \ldots \ldots \ldots \ldots \ldots \ldots \ldots . . . \ldots$

No Such Post Office ................... 2

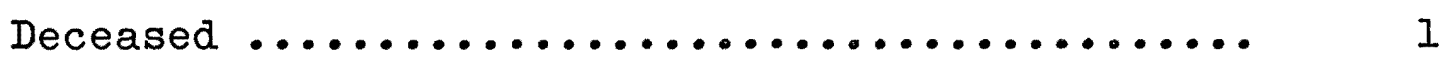

Stamped Reason Illegible $\ldots \ldots \ldots \ldots \ldots \ldots \ldots \ldots \ldots$

Total $\ldots \ldots \ldots \ldots \ldots \ldots \ldots \ldots \ldots \ldots$

The data were tallied and put into the computer for manipulation following the returns of the 24th day after the mailing. At the time of the cut-off, 295 or 45 percent of the questionnaires had been returned with complete enough information for use. Following the cut-off approximately 2 percent additional returns were received. These late returns were not added into the data pool. Data received was key-punched onto IBM cards and fed into the computer at Oregon State University. A terminal to this computer is located at the headquarters office of the 
Oregon Wildlife Commission in Portland. The data were tallied and analyzed statistically through the use of this computer. 
Notes

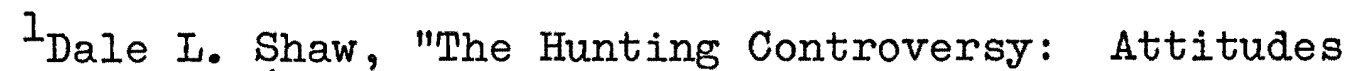
and Arguments" (Ph.D. dissertation, Colorado State University, 1973).

${ }^{2}$ Mildred Parten, Surveys, Polls and Samples: Practical Procedures (New York: Harper \& Brothers, 1950), p. 249.

3William G. Cochran, Sampling Techniques (New York: John Wiley and Sons, 1953).

${ }^{4}$ Ieslie Kish, Survey Sampling (New York: John Wiley \& Sons, 1965).

${ }^{5}$ George W. Snedecor, Statistical Methods (Ames, Iowa: The Iowa State Press, 1965).

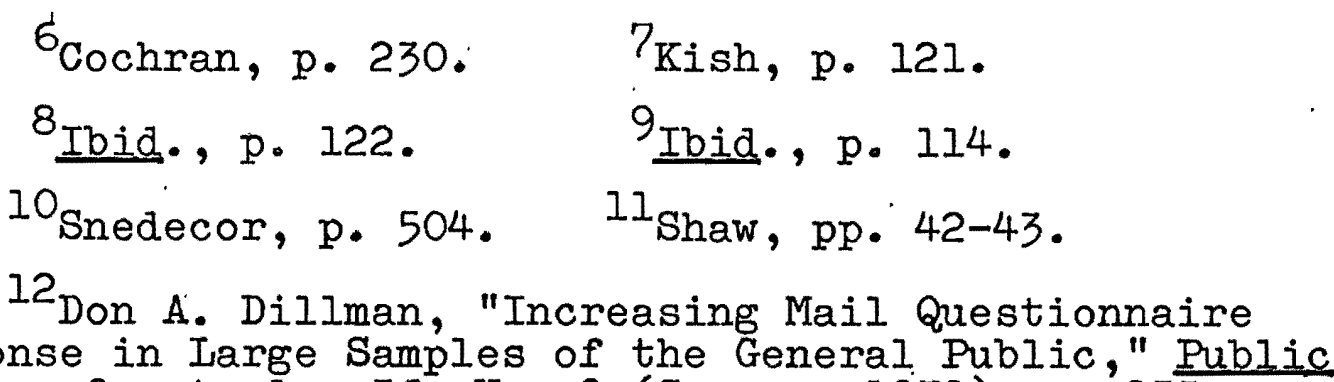
Response in Large Samples of the General Public," Public
Opinion Quarterly, 36, No. 2 (Summer, 1972), p. 255 . 


\section{CHAPTER IV}

\section{RESUIIS}

\section{GENERAI RESUITS}

\section{The Respondents}

1. Questionnaires were mailed to 711 individuals selected from. Oregon telephone books. Fifty-one or 7 percent of the questionnaires were returned as "Undeliverable" by the U.S. Postal Service.

2. Of the 660 questionnaires delivered, 295 or 45 percent were returned with adequate information.

3. Males made up 79.3 percent of the respondents, females 18.6 percent, and 2.1 percent did not indicate their sex.

4. Ages of the respondents ranged from 17 through 87 with a mean of 46.5 years.

5. Slightly over one-fourth of the respondents indicated rural residences, 44 percent indicated residences in the Portland metropolitan area, the remainder in the two smaller metro areas or in smaller cities and towns.

6. Forty-five percent of the respondents hunt, 56 percent fish. 
The Sources of Information

and Ideas on Wildlife

1. Television. Seventy-three percent of the respondents indicated television as a source of information and ideas concerning wildlife. This was the most commonly mentioned source. Most frequently mentioned programs were: Wild Kingdom, Outdoor Sportsman with Jim Conway, Jacques Cousteau, National Geographic Specials, American Sportsman, Walt Disney Presents, Untamed World, and Animal World.

2. Personal Experience. Second most frequent source of ideas and information was personal experience. Of the respondents 68 percent indicated this furnished them ideas and information. Most commonly mentioned were fishing, hunting, and hiking trips.

3. Newspapers. As a source of information 58 percent reported newspapers. The most commonly mentioned single source was columns by Don Holm followed by the Northwest section of the Oregonian. Third in frequency was the Oregonian in general.

4. Magazines. Magazines were listed by 55 percent of the respondents as a source. Field and Stream was most often named followed closely by outdoor life. Third most frequently mentioned was Oregon Wildlife or the Game Commission Bulletin followed by National Geographic.

5. Friends. Almost half ( 49 percent) of the respondents indicated friends were a source of ideas and information about wildlife. Hunting and fishing companions were 
the most frequently mentioned.

6. Other. In descending order, other sources mentioned were: Movies (28 percent), Organizations (26 percent), Parents (24 percent), Radio (15 percent), and Teachers (10 percent).

\section{Attitudes Toward Hunting}

Of the total of 267 who answered the question concerning their attitude toward hunting, 23 percent indicated some degree of opposition, 20 percent were neutral, and 57 percent indicated. some degree of approval of hunting $(N=267)$. On a seven-point scale, 8 percent of the males and 31 percent of the females rated themselves as very much against hunting. Conversely, 50 percent of the males and 14 percent of the females indicated they were very much for hunting.

\section{THE RESPONDENTS}

The recipients of the questionnaire were asked to indicate their sex, age, size of home community, and whether they hunted or fished. The response indicated a bias toward males as would be expected from a telephone book sample since most telephone numbers in households are listed under the name of the male head of the household. Summarized data are found in Table II. 
TABLE II

SEX OF RESPONDENTS

\begin{tabular}{lcc}
\hline Sex & Number & Percent \\
\hline Male & 234 & 79.3 \\
Female & 55 & 18.6 \\
Not Indicated & 6 & 2.1 \\
\hline
\end{tabular}

A tally of the age of the respondents and frequencies may be found in Appendix C. Summarized data on age is found in Table III.

TABLE III

AGE DATA SUMMARY

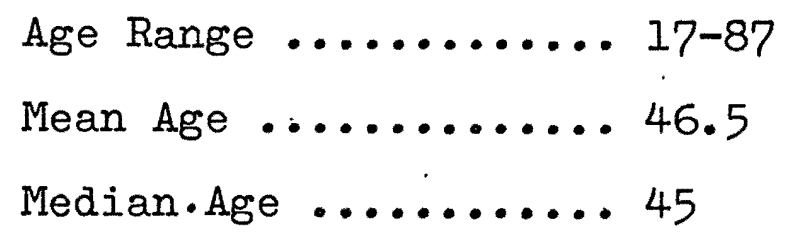

According to the Portland State University Center for Population Research and Census, the mean age of Oregon residents in 1970 was slightly over 27 years. No data were available concerning the mean age of residents over 17.

Size of home community was broken into four categories. Shaw found that 26 percent of the students came from rural communities, however his breakdown for larger areas was not comparable to this study since he was dealing with 
individuals from areas larger than any metropolitan areas fourd in Oregon.

In 1970, according to the Center for Population Research and Census, Oregon's mural population comprised approximately 33 percent of the total state population. The respondents indicated rural dwelling places in 28.7 percent of the cases. Shaw gave no clear definition of a rural dwelling, but the lower limit of the preceding category was a city of 10,000 .

\section{SOURCES OF INFORMATION}

Results of the survey indicate that the general overall trend of information use of Shaw's 'students and the individuals surveyed in Oregon are similar, but there are notable variations.

The Oregon citizens indicated a much greater use of the media in obtaining general wildlife information than did the students in obtaining anti-hunting attitudes. Oregon citizens indicated an average of 4.1 sources utilized compared to 1.8 in the case of Shaw's students. Shaw's students indicated both personal experience and television as top sources of anti-hunting ideas, but only 38 percent of them chose these as sources. In contrast the Oregon citizens named television as a source of general wildiffe information 73 percent of the time and personal experience 68 percent of the time. 
In only one category did the student's dependence on a source surpass that of the Oregonians. Of the students 27 percent indicated receiving anti-hunting attitudes from their parents while only 24 percent of the Oregonians marked this category as a source of general wildlife information.

Figure 1 compares the percentages indicated by the two groups. 
40

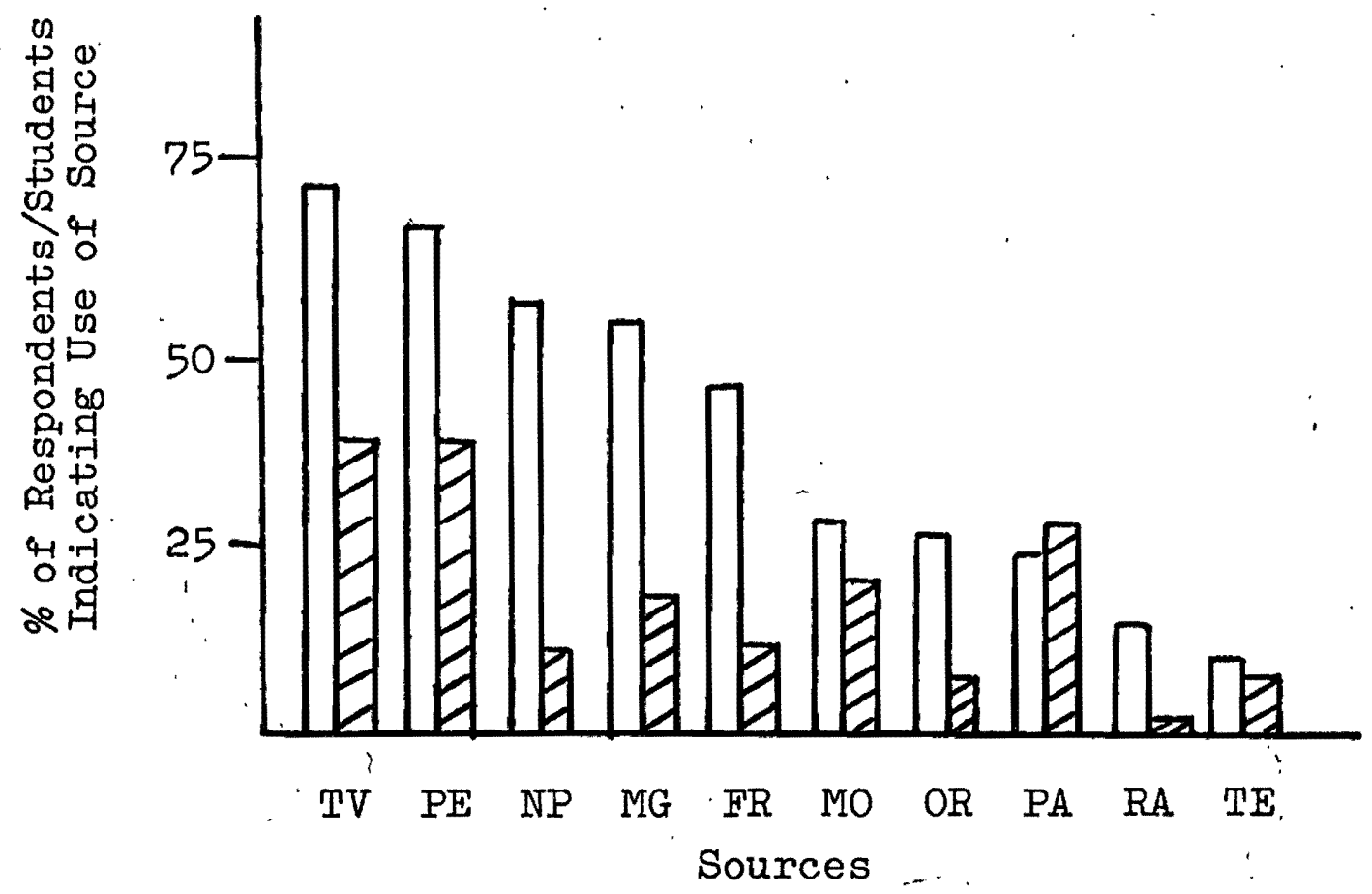

$$
\begin{array}{rlrl}
W & =\text { Shay Respondents } & \mathrm{N}=295 & \bar{x} \text { Responses }=4.1 \\
& =\text { Shaw Students } & \mathrm{N}=937 & \overline{\mathrm{x} R e s p o n s e s}=1.8 \\
\mathrm{TV} & =\text { Television } & \text { MO }=\text { Movies } \\
\mathrm{PE}=\text { Personal Experience } & \text { OR }=\text { Organizations } \\
\text { NP }=\text { Newspapers } & \mathrm{PA}=\text { Parents } \\
\text { MG }=\text { Magazines } & \mathrm{RA}=\text { Radio } \\
\text { FR }=\text { Friends } & \text { TE }=\text { Teachers }
\end{array}
$$

Figure 1. Histogram comparing percentage of Shay respondents and Shaw students indicating use of various sources. 
TABLE IV

SOURCES OF WIIDLIFE INFORMATION AND IDEAS

AS INDICATED BY NUMBER AND PERCENTAGE

BY OREGON RESPONDENTS

\begin{tabular}{|c|c|c|c|c|}
\hline Source* & $\begin{array}{l}\text { No. of } \\
\text { Males }\end{array}$ & $\begin{array}{l}\text { No. of } \\
\text { Females }\end{array}$ & Total & $\begin{array}{l}\% \text { of } \\
\text { Respondents }\end{array}$ \\
\hline $\mathrm{TV}$ & 171 & 44 & 215 & 73 \\
\hline Personal Experience & 170 & 32 & 202 & 68 \\
\hline Newspapers & 146 & 25 & 171 & 58 \\
\hline Magazines & 138 & 24 & 162 & 55 \\
\hline Friends & 128 & 18 & 146 & . 49 \\
\hline Movies & 60 & 23 & 83 & 28 \\
\hline Organizations & 65 & $1 \dot{2}$ & 77 & 26 \\
\hline Parents & 53 & 17 & 70 & 24 \\
\hline Radio & 36 & 8 & 44 & 15 \\
\hline Teachers & 22 & 8 & 30 & 10 \\
\hline 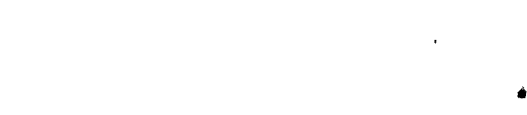 & $\overline{989}$ & $2 \overline{11}$ & 120 & \\
\hline
\end{tabular}

*More than 1 source could be mentioned by respondent. 


\section{TABLE V}

SOURCES BY NUMBER AND PERCENTAGE WHICH SHAW'S STUDENTS REPORTED HAD INFLUENCED

THEM AGAINST HUNTING

\begin{tabular}{|c|c|c|c|c|}
\hline Source* & $\begin{array}{l}\text { No. of } \\
\text { Males }\end{array}$ & $\begin{array}{l}\text { No. of } \\
\text { Females }\end{array}$ & Total & $\begin{array}{c}\% \text { of Students } \\
\text { Sampled }\end{array}$ \\
\hline TV & 150 & 204 & 354 & 38 \\
\hline Personal Experience & 193 & 162 & 355 & 38 \\
\hline Newspapers & 35 & 65 & 100 & 11 \\
\hline Magazines & 96 & 77 & 173 & 18 \\
\hline Friends & 52 & 62 & $\cdot 114$ & 12 \\
\hline Movies & 69 & 119 & 188 & 20 \\
\hline Organizations & 37 & 42 & 79 & 8 \\
\hline Parents & 98 & 152 & 250 & 27 \\
\hline Radio & 3 & 6 & 9 & 1 \\
\hline \multirow[t]{2}{*}{ Teachers } & 18 & 49 & 67 & 7 \\
\hline & $\overline{751}$ & $\overline{938}$ & $\overline{1689}$ & \\
\hline
\end{tabular}

*More than 1 factor could be mentioned by the individual student. 
When comparing the number of responses in any one source to the total number of responses of the students or the Oregonians, a similar pattern is evident. Television and personal experience are still very important to both groups. However, teachers and movies, in addition to parent are sources utilized more often by the students than by the Oregonians. Students also indicated greater dependence on television and personal experience than the adults, but the proportionate difference was less than in the other categories. 
44

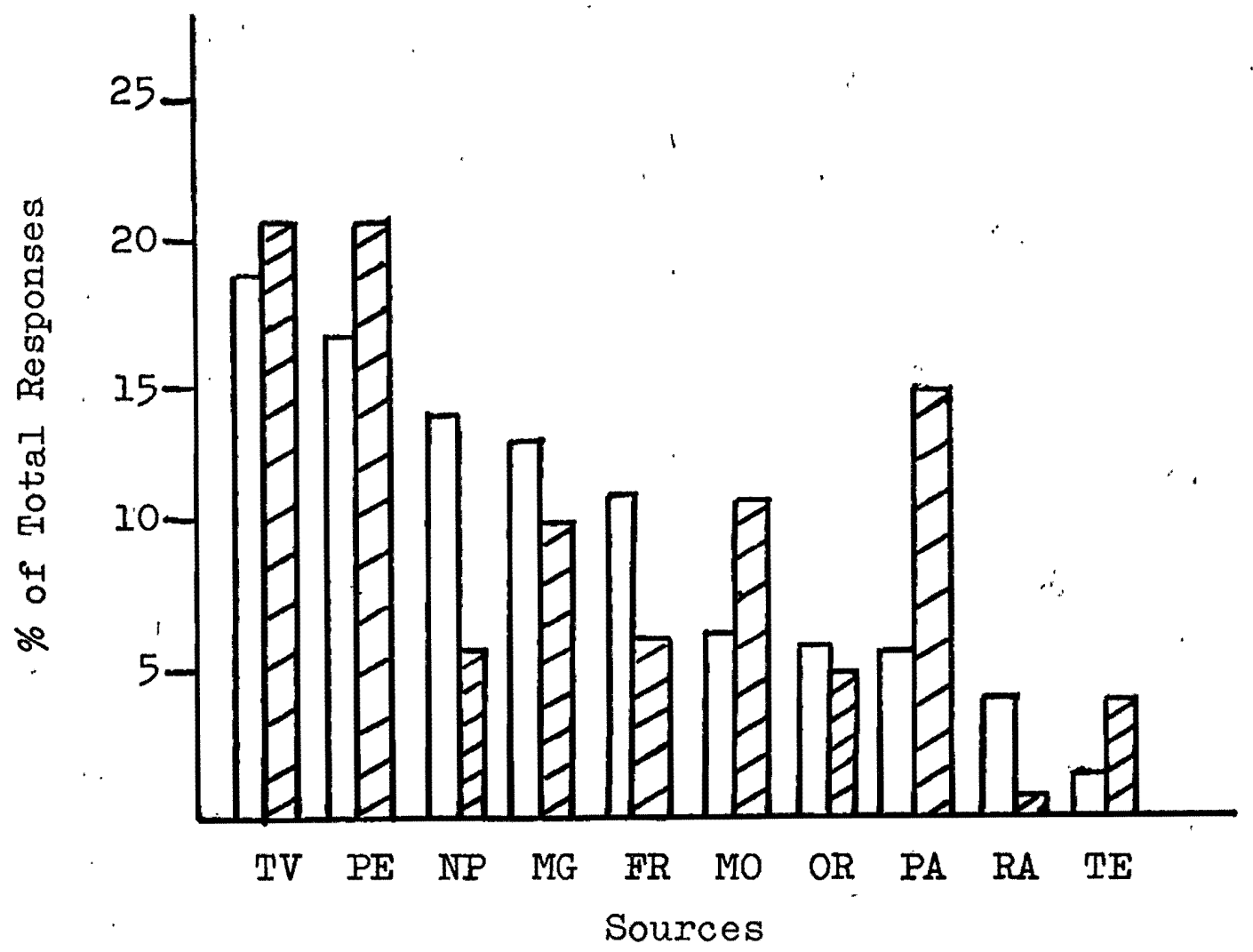

$$
\begin{aligned}
& \prod=\frac{\text { Shay Respondents Responses }}{\text { Total No. of their Responses }} \quad \mathrm{N}=1200 \\
& \nabla=\frac{\text { Shaw Students Responses }}{\text { Total No: of their Responses }} \quad N=1689 \\
& \mathrm{TV}=\text { Television } \quad \text { MO }=\text { Movies } \\
& \mathrm{PE}=\text { Personal Experience } \quad \mathrm{OR}=\text { Organizations } \\
& \text { NP }=\text { Newspapers }, \quad \text { PA }=\text { Parents } \\
& \text { MG = Magazines } \\
& \mathrm{FR}=\text { Friends } \\
& \mathrm{RA}=\text { Radio } \\
& \mathrm{TE}=\text { Teachers }
\end{aligned}
$$

Figure 2. Histogram comparing percentage of Shay respondents and Shaw students responses by sources with total responses. 
TABLE VI

SOURCES PROVIDING INFORMATION BY

PERCENTAGE OF TOTAL SOURCES

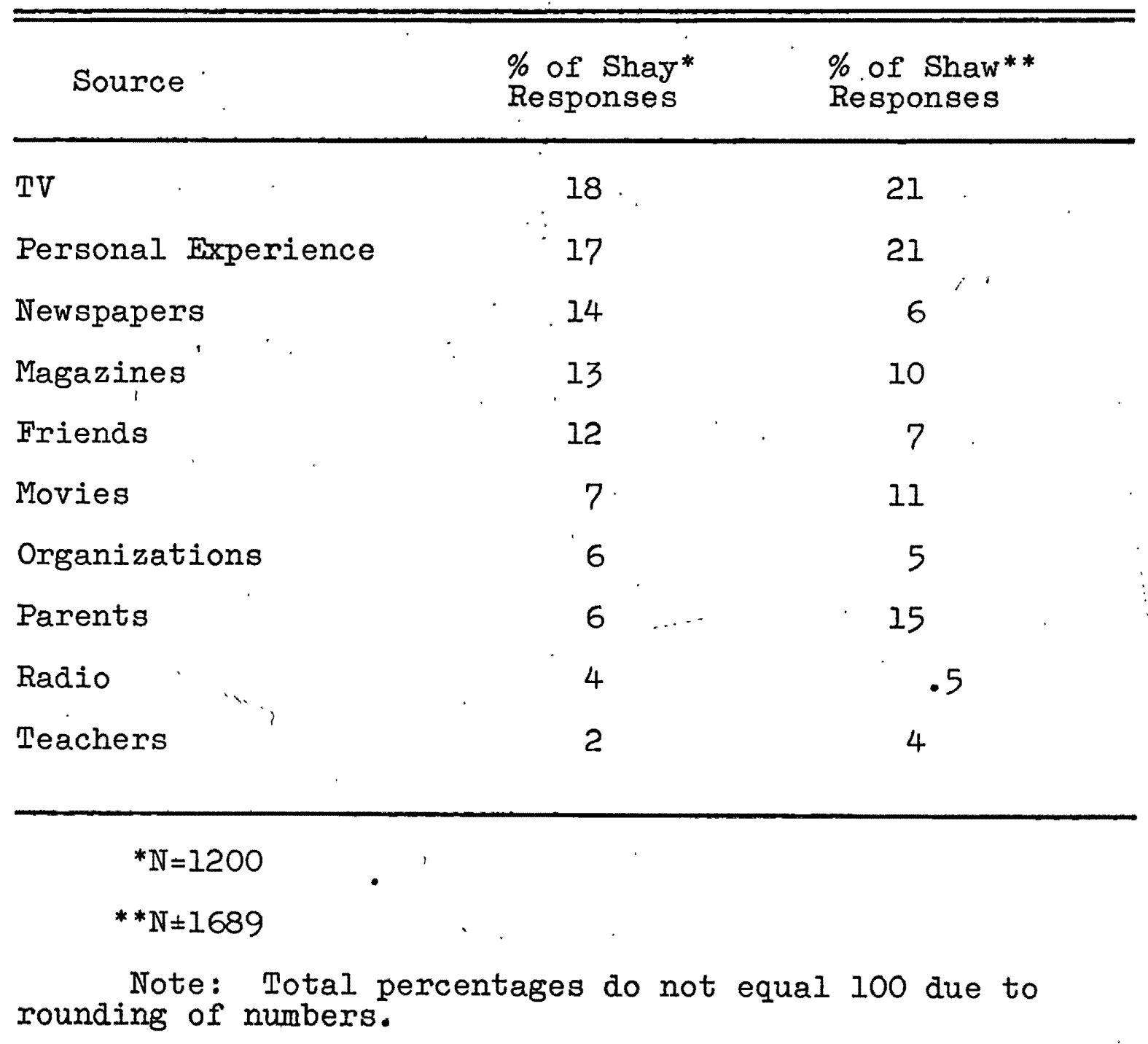


In addition to asking the respondents to indicate the basic sources of their wildlife information and ideas, they were asked to name any specific mass media programs they could recall and name other more specific sources within the broad major categorles. The complete results are included in Appendix $D$. 
TABLE VII

\section{SPECIFIC MEDIA PROGRAMS OR INDIVIDUALS \\ MOST FREQUENTLY MENTIONED AS SOURCES OF WIIDLIFE INFORMATION}

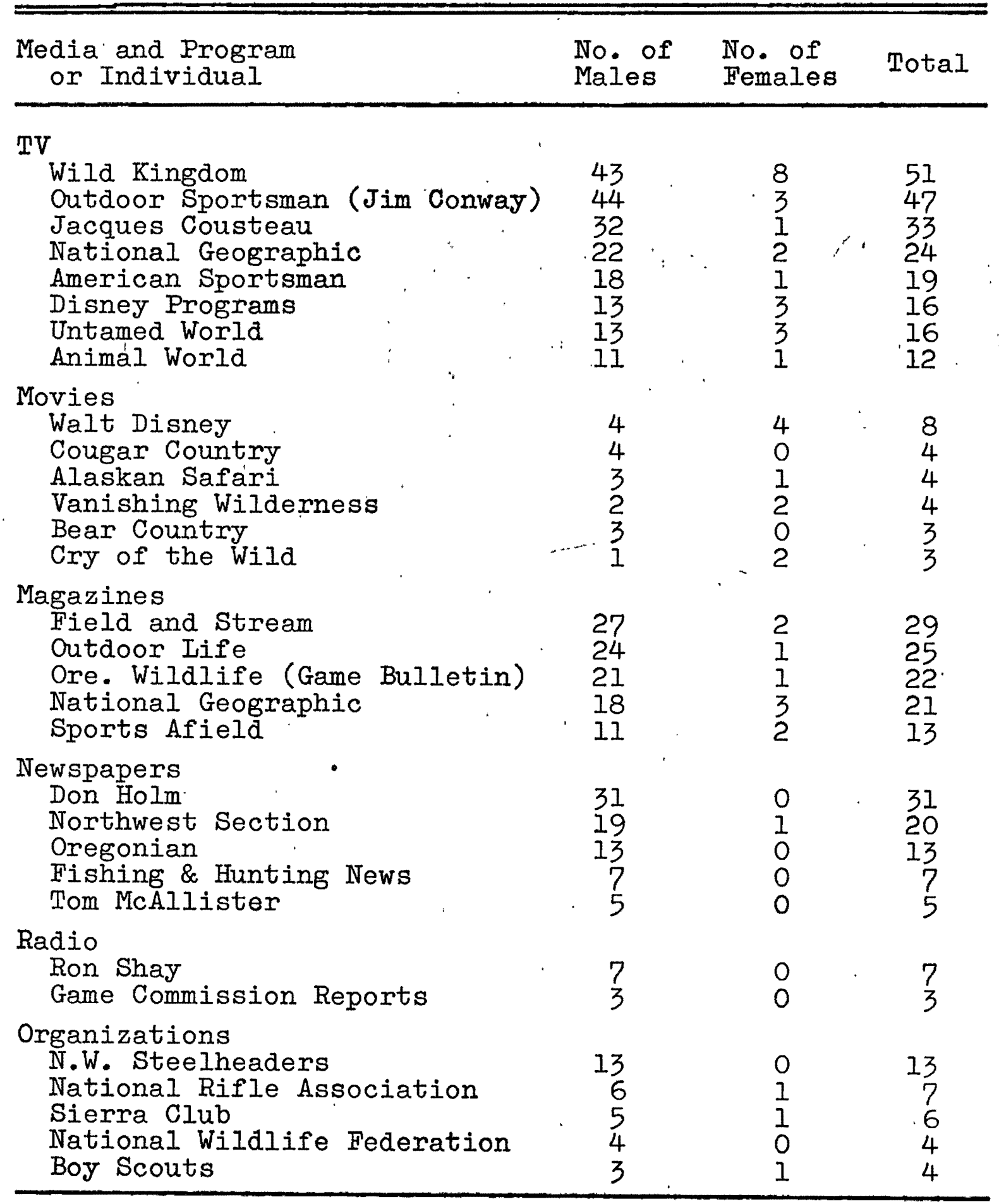


IV. NUMBER OF RESPONDENTS WHO HUNT AND FISH AND ATTITUDES TOWARD HUNTING

In recent years there has been an upswelling of antihunting sentiment and this is what Shaw was measuring in addition to the sources of the sentiment. This study was designed to measure a different variable, however because it is related, questions were included on participation in hunting and angling and the attitude toward hunting.

As is the traditional pattern, it was revealed that a greater percentage of the male respondents participated in both sports than did female respondents and that more females fished than hunted (see Appendix E).

The relationship of size of home community and participation in hunting and fishing is shown in Appendix $F$.

\section{Attitudes Toward Hunting}

The respondents in the Oregon Survey were largely in favor of hunting. In this questionnaire, the term hunting was not defined to leave the response as broad as possible. Many individuals class with hunting the commercial taking of whales, poaching, and various illegal activities. Despite this, over 50 percent of the persons answering the question were in some degree favorable to hunting. The males were heavily in favor of hunting, while in the females the response was the opposite, however, a much larger percentage of females were neutral (see Appendix G). 


\section{CHAPTER V}

\section{SUTMMARY AND CONCLUSIONS}

\section{SUMMARY OF RESUITS}

The specific question that this study was designed to investigate was: What sources of information are most commonly utilized by a sample of Oregon's adult population in obtaining ideas and information concerning the wildlife resource and how comparable are the proportions of various sources utilized with those indicated by college students as sources of anti-hunting sentiment?

The study was based on the assumption that college students and adults both received information in the same amount from the same general sources. The previous study paralleled by this study investigated the sources of anti-

- hunting sentiment in college students at ten randomly selected schools in the United States.

Iittle has been done to try to measure the relative impact of the various media and other sources of information. This study does not answer the question of impact, but it does show where the subjects of the study feel they are getting their ideas and information concerning the wildlife resource of the state of Oregon. 
The results of the anti-hunting sentiment study with students were compared with the results of this study. The general pattern of the relative use of the various sources was similar in most respects. However, the sample of Oregon adults reported using most of the sources to a greater degree. In one instance, the source being teachers, the pattern of use was reversed between the two groups. In all other instances, the adults used the sources more than did the students. In the case of the teachers as a source, the students reported getting anti-hunting information from them more than the adults indicated getting general wildlife information from them.

In this category, such a result could be anticipated since the students were all in colleges and universities and their teachers are a major source of input to them at this stage in life.

Hypothesis: There will be no significant difference in the proportion of information sources utilized with respect to general information about wildlife by Oregon adults and acquisition of anti-hunting sentiments by a nationwide sample of college students.

The null hypothesis was rejected. Though the general pattern of source use is similar between the two groups, the amount. of use reported in percentage of respondents indicating a source, varies considerable. As was mentioned 
previously the utilization of one source was completely reversed from the parallel pattern.

The Oregon citizens indicated a considerably greater amount of use of the various sources in obtaining broad, general information regarding wildlife as compared to students' use in obtaining anti-hunting sentiment. However, in proportion of responses attributed to individual sources as compared to total responses, there was more similarity in some categories. The results, when plotted on a histogram, do reveal the similarity of pattern in the relationship of use between the various sources. For example, television and personal experience were the most often indicated sources by the adults. The same was true for the students in their responses. The major difference lies in the proportion of students and adults listing these sources. Of. the students, 38 percent indicated they received antihunting information from these sources while over 70 percent of the adults indicated getting information and ideas about wildlife from these sources. This pattern is generally true in the lesser used categories with the one exception, teachers, that was noted.

\section{CONCLUSIONS}

The results of the study have produced information of value to resource managers and communicators. The expected 
similarities in the pattern of information source use are not as close as one might assume.

Persons interested in hunting and fishing probably use the sources more to get the kind of information they want, but may interpret what is seen in a fashion different from other viewers.

The study has confirmed the conclusion of some writers that people tend to seek material from the mass media that is compatible with their pre-existing ideas. The adult sample indicated they get information and ideas about wildife from a greater number of sources than the students. The sample contained a large proportion of hunters and anglers and persons who approve of hunting.

The most often mentioned television program by both groups was the same one. This could well be because it is one of the very few wildlife programs presented by a major network in prime time.

It would appear that the main thrust of further studies should be to further analyze how the various groups interpret the material presented in such programs. The show Wild Kingdom was number one in both groups. One group considered itia source of anti-hunting information. The other group considered it simply as a source of ideas and information, although they were not asked if they thought it might have anti-hunting overtones. 
Generally, it would seem the wildlife management communicators will be able to reach both the audiences surveyed to somewhat the same degree through the various sources. The casually or not interested still will not use the sources as much as the interested. However, perhaps more importantly, it would appear that there may be varying interpretations of the material presented.' It would behoove the communicator to carefully pre-test program material if possible using non-interested persons. Since he is trying to get across the point that hunting is a valid, non-threatening, wildlife management tool he may be working against himself if his materials put across an antihunting message inadvertently.

A great number of the programs mentioned were either of network origin, syndicated or nationally distributed movies. In Oregon the second most frequently mentioned television program was of local origin suggesting that interested persons will watch and remember a certain type of local production. The Oregon show is basically a "catch and kill" program with little time devoted to wildlife management philosophies and problems.

It is apparent though, of the mass media, television has the greatest potential for putting forth both information and misinformation concerning wildlife. Also, it has been apparent that it is much easier to elicit emotional responses than put across factual material. With this 
study and the one by Shaw, the wildlife communicator has a place to begin to try to do his job of informing the public concerning the true problems of our wildlife resource. With these studies, he can hopefully better allocate his time and resources and better tailor his materials to accomplish the end he desires.

\section{SUGGESTIONS FOR FURTHER RESEARCH}

This study and that of Shaw have barely broken the ground of investigation that needs to be done. The directions that further study might take are myriad, however several areas seem to demand more thorough investigation as soon as they can be accomplished.

1. How do individuals with different interests and biases interpret the same material? There is little doubt. that each individual processes external input differently. It would be useful to know if there are patterns that might be discovered in the processing carried on by groups of individuals with similar biases, such as anti-hunting or pro-hunting feelings. Also, equally as important, how do those who have little or no interest in the subject of wildlife respond to programs that supply information to the other groups?

2. Investigation of the characteristics of the nonrespondents to a survey such as this one. It would be desirable to know if the non-respondents did not respond 
because they felt they had no information to offer, were not interested in the whole thing, or had other reasons. If the time and funds were available a complete personal follow-up on these individuals would be revealing.

3. Study to determine the depth of understanding of materials presented by the various sources, Though television is the most often used medium by both students and older individuals, does it do the best job of informing the viewer of the complex ideas being presented? One reaction to the results of these studies might be to devote a tremendous amount of time and effort to the use of television to the detriment of the other sources. Yet, is the medium putting across sound, basic information or just eliciting emotional responses that tend to foster antihunting ideas?

The data collected in the study could be further examined for relationships not discussed here such as the characteristics of anti-hunting and pro-hunting Oregonians, the comparison of the characteristics of this sample with Oregon demographic characteristics, and numerous other correlative analyses. 


\section{A SELECTED BIBLIOGRAPHY}

Berelson, Bernard and Steiner, Gary A. Human Behavior. New York: Harcourt, Brace and World, Inc., 1964.

Cushing, William G., and Lewert, James B. "Has TV Altered Students' News Media Preferences?" Journalism Quarterly, 50, No. 1 (Spring, 1973), 138-141.

Cochran, William G. Sampling Techniques. New York: John Wiley and Sons, 1953.

Dasmann, William. If Deer Are To Survive. Harrisburg, Va.: Stackpole Books, 1971.

Davis, Iina J. "Exposure To and Attitudes Toward the Mass Media of Students at Sam Houston High School." M.A. thesis, North Texas State University, 1973.

Defleur, Melvin I. Theories of Mass Communication. New York: David McKay Co., 1970.

Dillman, Don A. "Increasing Mail Questionnaire Response in Large Samples of the General Public." Public Opinion Quarterly, 36, No. 2 (Summer, 1972), 254-257.

Elson, Robert E., and Sheridan, William R. "Broadcast Media-The Neglected Tool of P.R." Public Relations Quarterly, 16, No. 4 (1971), 3, 25-27.

Fish and Game Commission of Oregon. Biennial Report, 1917.

Gans, Herbert J. "The Critique of Mass Culture." Social Problems: A Modern Approach. New York: John Wiley and Sons, 1966.

Gilbert, Douglas I. Natural Resources and Public Relations. Washington, D.C.: The Wildlife Society, 1971.

Hendee, John C., and Schoenfeld, Clay. Human Dimensions in Wildlife Programs. Rockville, Maryland: Mercury Press, 1973. 
Hooper, Jon K. "Improving Wildlife Communications." University of California Cooperative Extension Paper presented at the annual meeting of Western Section of the Wildlife Society, Monterey, Calif., 1-2 February 1974.

Katz, Elihu. "On Reopening the Question of Selectivity in Exposure to Mass Communications." Theories of Cognitive Consistency. Chicago: Rand McNally, 1958.

Keel, Vernon A. "Leisure and The Mass Media: A Study of the Communications Behavior of Participants in a Major Area." Ph.D. dissertation, University of Minnesota, 1973.

Kish, Leslie. Survey Sampling. New York: John Wiley and Sons, 1965.

Klapper, Joseph T. The Effects of Mass Communication. Glencoe, Illinois: The Free Press, 1960.

"The Social Effects of Mass Communications.: The Science of Human Communication. New York: Basic Books, Inc., 1963.

Larsen, James A. "Science, Communications, Society." The Journal of Finvironmental Management, 5 , No. 1

Mills, C. Wright. "Mass Media and Public Opinion." Mass Media and Mass Man. Compiled by Alan Casty. New York: Holt, Rinehart and Winston, 1973.

Mitchell, Don M. "Help Needed." Oregon State Game Commission Bulletin, 11, No. 12 (December, 1956), 3, 6-7.

Parten, Mildred. Surveys, Polls and Samples: Practical Procedures. New York: Harper \& Brothers, 1950.

Rivers, William and Schramm, Wilbur. "The Impact of Mass Media." Mass Media and Mass Man. Compiled by Alan Casty. New York: Holt, Rinehart and Winston, 1973.

Roberts, Donald F. "The Nature of Communication Effects." The Process and Effects of Mass Communications. Urbana, Illinois: University of Illinois Press, 1971.

Roper, Elmo. "Reaching the General Public." Public Relations Quarter1y, 16, No. 2 (1971), 9-25. 
Schoenfeld, Clarence A. "Public Relations Aspects of Wildiffe Management." Journal of Wildlife Management, 21 , No. 1 (1957), 70-74.

Shaw, Dale I. "The Hunting Controversy: Attitudes and Arguments." Ph.D. dissertation, Colorado State University, 1973.

Snedecor, George W. Statistical Methods. Ames, Iowa: The Iowa State Press, 1965.

Stack, Robert. "Thanks to the Hunter." National Wildilife, 9, No. 6 (Oct.-Nov., 1971), 17.

Steinberg, Charles $S$. Mass Media and Communications. New York: Hastings House, 1966. 

THE QUESTIONNAIRE

$\mathrm{AGE}$ SEX

I live in:

Portland metropolitan area

Salem or Eugene-Springfield metropolitan area

A city 10,000 to 50,000

Rural area

I hunt fish do other outdoor activities (such as camping, hiking, boating, etc.)

(please name)

have no major outdoor recreational activities

We would like to know where you get your information and ideas about fish and wildlife. The following two pages list a number of sources of information and ideas about fish and wildlife. Please check those you think have provided you with finformation or ideas about fish and wildlife. When you have completed the questionnaire, please return it with this sheet in the enclosed prepaid envelope. We greatly appreciate your assistance and hope we will be able to serve you better in the future as a result of the information obtained in this questionnaire.

If you have any additional comments about fish and wildife, its management, or use, please feel free to use the other side of this page.

Thank you for your help. 
PLEASE CHECK those you feel have provided information or ideas on fish and wildlife.

1 Movies (name those you can remember)

Comment:

2 TV programs (name those you can remember)

Comment :

3 Magazine articles (name those you can remember) Comment:

4 Newspaper articles (name subject matter if you can remember it)

Comment :

5 Parents

Comment:

6 _ Personal experience (indicate nature of experiences) Comment: 
7

School teachers

Comment:

8

Friends

Comment:

9 Radio programs (name programs that you remember)

Comment:

10 __ Organizations (specify organizations)

Comment :

11

Other

Comment :

$\because$

12 One final question: How do you feel about hunting? Please rate your feeling on the following scale.

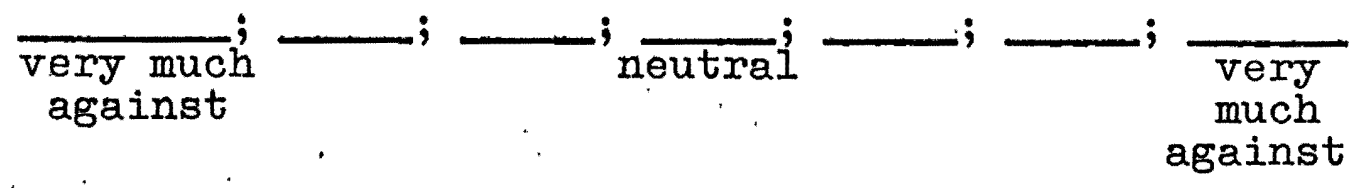





\section{CORRESPONDENCE}

THE COVER LETTER

April 1974

Dear Oregonian:

The Oregon Wildlife Commission is charged with the management of the wildlife and sport fishery resource of Oregon. . In order to do the best job possible, I) WE NEED TO. KNOW YOUR WISHES and 2) WE NEED TO KNOW HOW TO BEST LET YOU KNNOW WHAT WE ARE DOING.

Attached is a short questionnaire. If you would help us by taking a few minutes to fill it out and return it in the enclosed envelope, it would be greatly appreciated. We are simply trying to find out how we can best pass along information concerning Oregon's wildlife and the problems it is facing. You are part of a very small sample of Oregon residents that are receiving this, so your response will indeed make a difference. Your individual responses wlll be kept confidential.

Thank you for your assistance.

Sincerely,

Ron E. Shay, Assistant Chief Information \& Education Division Enclosures 
We're looking for our questionnaires concerning your sources of information on fish and wildlife.

If you have already sent jours back, we thank you.

If you haven't returned the filled out questionnaire, we would certainly appreciate it if you'd take a few minutes to do so. What you have to say is very important.

Thank you for your help

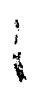

Ron Shay

Information-Education Division Oregon Wildlife Commission P.0. Box 3505

Portland, Or. 97208 
1

APPENDIX C

AGES OF RESPONDENTS 
AGES OF RESPONDENTS

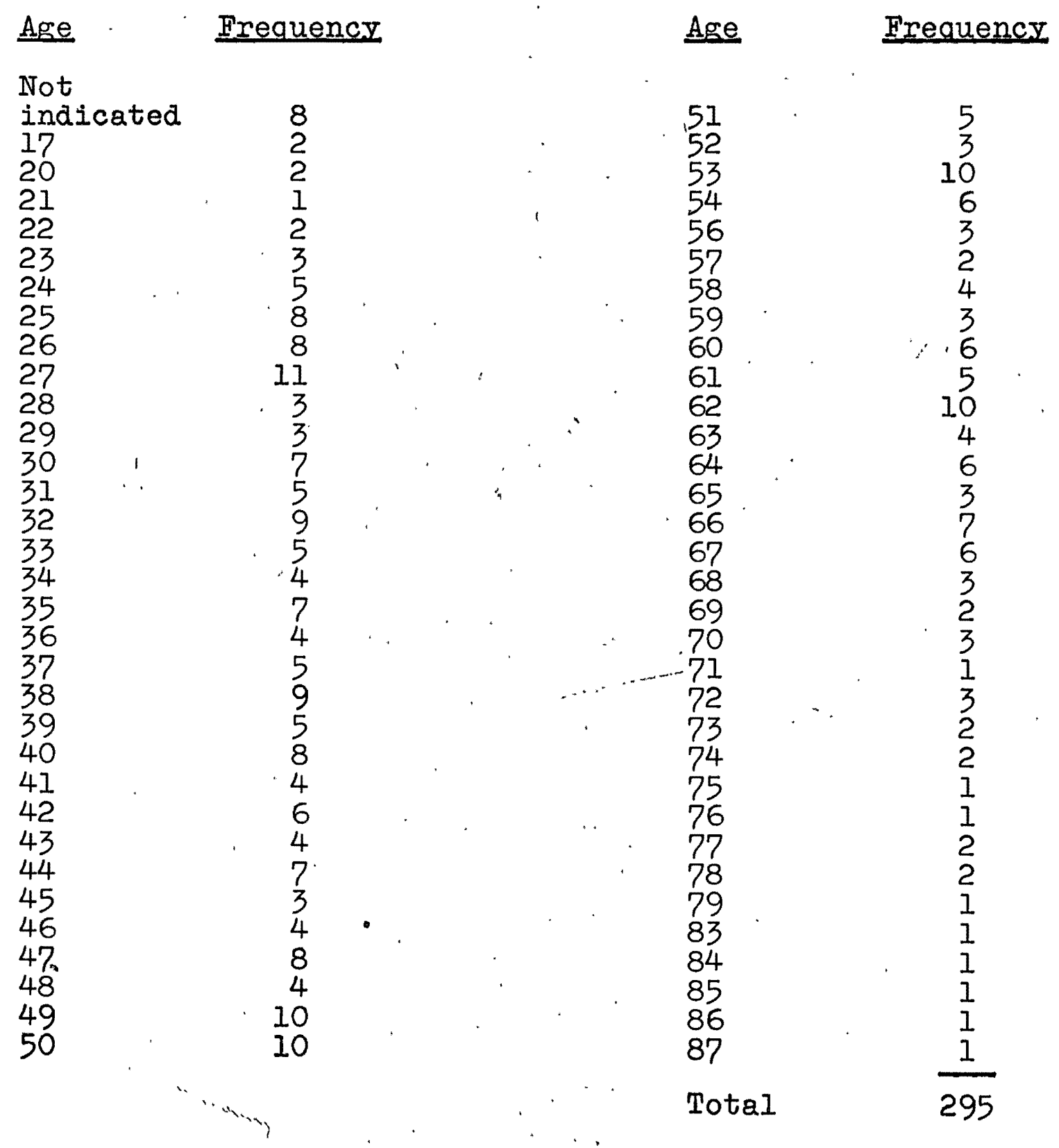




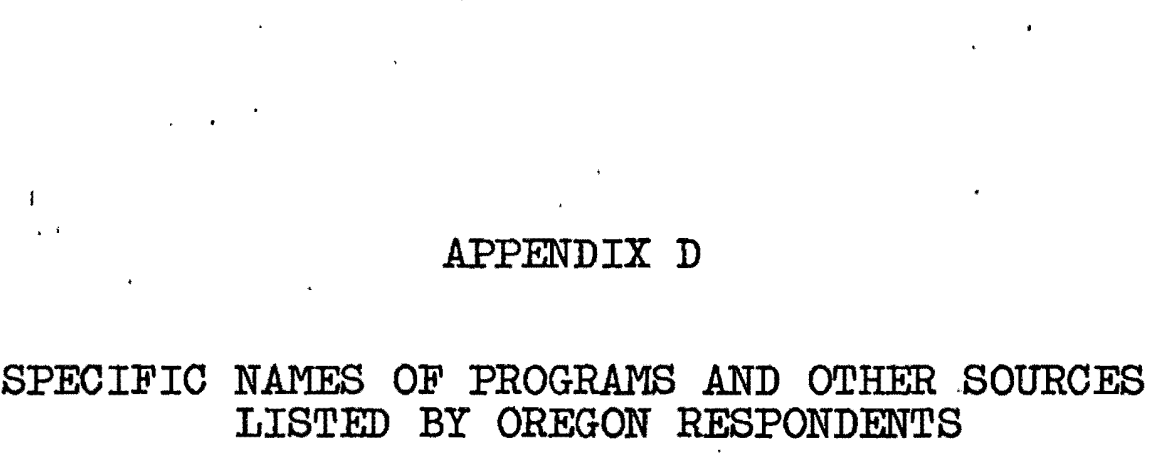
RESPONDEI 


\section{SPECIFIC NAMES OF PROGRAMS AND OTHER SOURCES IISTED BY OREGON RESPONDENTS}

\section{Source}

No. of Times Mentioned

Television

Wild Kingdom

Outdoor Sportsman (Jim Conway)

51

Jacques Cousteau

National Geographic Specials

American Sportsman

Disney Programs

Untamed World

Animal World

National Audubon Theatre

Channel 10

Bill Burrud

World of Survival

High \& Wild

Ron Shay

Say Good Bye

Gaddabout Gaddis

Spot Announcements

Daktari

Red Dunning

Lets Go Fishing

Newspaper

Oregonian--Don Holm

Oregonian--Northwest Section

Oregonian

- Fishing \& Hunting News

Tom McAllister

Medford Mail Tribune

Journal (Oregon)

Pete Cornacchia

Portland Scribe

Enterprise Courier

Oregon Daily Emerald

Ray Stose

Bend Bulletin

Fred Goetz, Labor Press

Herald \& News

- Register Guard .

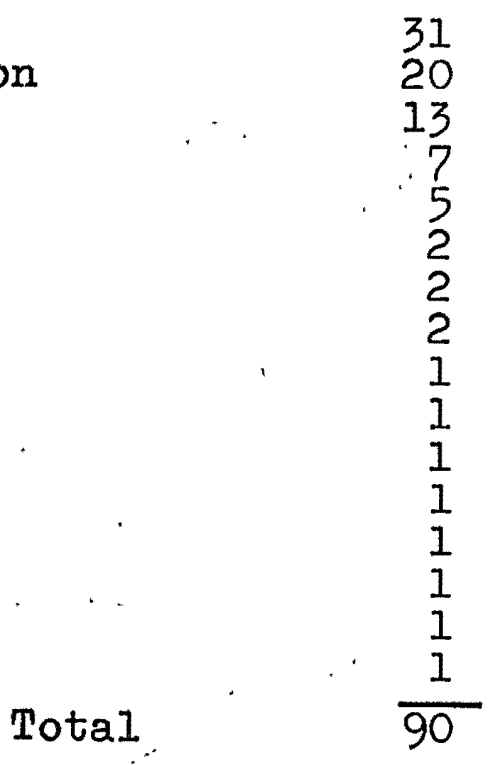


Source

Magazines

Field and Stream , 29

Outdoor Life 25

Ore. Wildlife (Game Comm. Bulletin) 22

National Geographic 21

Sports Afield . 13

National Rifleman

Sunset

National Wildlife

Readers Digest

True

Salmon-Trout-Steelhead

Western Outdoors

Parade

Wilderness Camping

Time

Bow Hunters

Pacific Wilderness Journal

Audubon

Elks

Natural Science

Argosy

American Hunter

Smithsonian

Idaho Wildlife

Fly Fishing

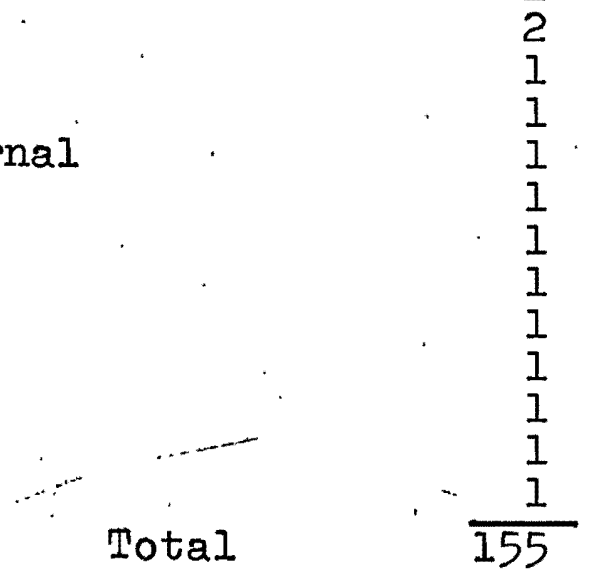

Movies

Walt Disney

Cry of the Wild

Cougar Country

Alaskan Safari

Vanishing Wilderness

King of the Grizzlies (Night of)

Bear Country

Brother of the Wind

Beaver Valley

Wild River

Charlie, The Ionesome Cougar

Olympic Elk

The Living Desert

North Country

Realm of the Wild

Way of a Trout.

Total 
$\underline{\text { Source }}$

No. of Times Mentioned

Organizations

N.W. Steelheaders

National Rifle Association

Sierra Club

Boy Scouts

National Wildife Federation

Audubon Society

Ducks Unlimited

Forest Service

Friends of Earth

Izaak Walton League

Mazamas

Oregon Fish and Game Commission

Adventures Unlimited

Bass \& Panfish Club

Bend Bowmen

Dalles Rifle \& Pistol Club

Four Corners Rod \& Gun

Hillsboro Rod \& Gun Club

Environmental Defense Fund

Multnomah Hunters \& Anglers

Native Plant Society

Oregon Environmental Council

Oregon Museum of Science and Industry

Wamic Sportsmen's Club

Total

13

$?$

4

4

2

2

2

2

;

(1)

1

1

1

1

1

1

1

1

$\frac{1}{60}$

Radio

Ron Shay

Game Commission Reports

Spot Announcements

KMMED

Fish Watch

Total

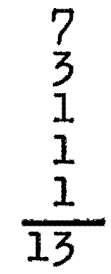


PARTICIPATION BY SEX

TABLE VIII

PARTICIPATION IN HUNTING AND FISHING BY SEXX

\begin{tabular}{ccccc}
\hline Sex & \multicolumn{2}{c}{ Hunt } & \multicolumn{2}{c}{ Fish } \\
\hline Males & No. & $\%$ & No. & \\
Females & 129 & 55 & 180 & 77 \\
1 & $\frac{5}{134}$ & 9 & $\frac{24}{168}$ & 44 \\
\hline
\end{tabular}




$$
-
$$




\title{
CHARACTERISTICS OF RESPONDENTS \\ COMPARED TO SIZE OF \\ HOME COMMUNITY
}

\begin{abstract}
TABLE IX
RESPONDENTS BY SIZE OF HOME COMMUNITY
\end{abstract}

\begin{tabular}{lcccc}
\hline \hline Size of Community & Male & Female & Total* & $\%$ \\
\hline Portland Metro Area & 93 & 32 & 125 & 44.8 \\
Eugene-Salem Area & 26 & 9 & 35 & 12.5 \\
City 10,000-50,000 & 36 & 3 & 39 & 14.0 \\
Rural & 71 & 9 & 80 & 28.7 \\
\hline
\end{tabular}

*Sixteen did not indicate.

Note: Chi Square data is included for those who may be interested. It is not discussed.

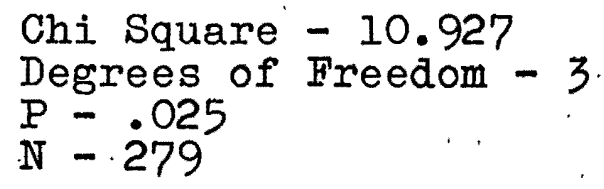




\section{TABLE X}

RESPONDENTS WHO HUNT BY SIZE OF HOME COMMUNITY BY NUMBER AND PERCENT

\begin{tabular}{lccc}
\hline \hline Size of Community & $\begin{array}{c}\text { No. Who } \\
\text { Hunt }\end{array}$ & $\begin{array}{c}\% \text { of Those } \\
\text { Who Hunt }\end{array}$ & $\begin{array}{c}\text { No. Who Do } \\
\text { Not Hunt }\end{array}$ \\
\hline Portland Metro Area & 41 & 30.8 & 84 \\
Eugene-Salem Area & 11 & 8.2 & 24 \\
City 10,000-50,000 & 26 & 19.5 & 13 \\
Rural, & 55 & 41.3 & $\frac{29}{150}$ \\
& $\frac{53}{133^{*}}$ & & \\
\hline
\end{tabular}

* $45 \%$ of total respondents.

Note: Chi Square data is included for those who may be interested. It is not discussed.

Chi Square - 31.09

Degrees of Freedom - 3

$\mathrm{P}-.0000$

$F-283$ 
TABLE XI

RESPONDENTS WHO FISH BY SIZE OF HOME COMMUNITY

BY NUMBER AND PERCENT

Size of Community $\begin{gathered}\text { No. Who } \\ \text { Fish }\end{gathered} \quad \begin{gathered}\% \text { of Those No. Wish } \\ \text { Who Fo }\end{gathered}$ Not Fish

$\begin{array}{lccr}\text { Portland Metro Area } & 78 & 38.6 & 47 \\ \text { Eugene-Salem Area } & 23 & 11.3 & 12 \\ \text { City 10,000-50,000 } & 35 & 17.3 & 4 \\ \text { Rural 1 } & \frac{66}{202^{*}} & 32.6 & \frac{18}{81}\end{array}$

* $68 \%$ of total respondents.

Note: Chi Square data is included for those who may be interested. It is not discussed.

Chi Square - 14.0.

Degrees of Freedom - 3

$\mathrm{P}-.0000$

$\mathrm{N}-283$ 
APPENDIX G

HUNTING ATTITUDES 
HUNTING ATTITUDES

TABLE XII

ATTITUDES TOWARD HUNTING BY NUMBERS AND PERCENT

\begin{tabular}{|c|c|c|c|c|c|c|}
\hline Attitudes & $\begin{array}{l}\text { Ma: } \\
\text { No. }\end{array}$ & es $\%$ & $\begin{array}{l}\text { Fen } \\
\text { No. }\end{array}$ & $\begin{array}{l}\text { les } \\
\%\end{array}$ & Total & $\begin{array}{l}\% \text { of Those } \\
\text { Answering }\end{array}$ \\
\hline 1 - Very Much & 18. & 8 & 15 & 31 & 33 & $\therefore 12$ \\
\hline 2 & 15 & 7 & 4 & 8 & 19 & 7 \\
\hline $3 \quad 1$ & 8 & 4 & 2 & 4 & 10 & 4 \\
\hline 4 - Neutral & 36 & 16 & 17 & 35 & 53 & 20 \\
\hline 5 & 21 & 10 & 2 & 4 & 23 & 9 \\
\hline 6 & 12 & 5 & 2 & 4 & 14 & 5 \\
\hline 7 - Very Much For & $\frac{111}{221}$ & 50 & $\frac{6}{48}$ & 13 & $\frac{117}{269}$ & 43 \\
\hline
\end{tabular}

Note: Chi Square data is included for those who may be interested. It is not discussed.

Chi Square - 38.986

Degrees of Freedom - 6

$\mathrm{P}=.0000$ (Sig. .05)

N -269 
TABLE XIII

ATTITUDE TOWARD HUNTING BY

SIZE OF HOME COMMUNITY

\begin{tabular}{|c|c|c|c|c|c|c|c|c|}
\hline \multirow[t]{2}{*}{$\begin{array}{l}\text { Size of } \\
\text { Community }\end{array}$} & \multicolumn{2}{|c|}{$\begin{array}{l}\text { Very } \\
\text { Much } \\
\text { Against }\end{array}$} & \multicolumn{3}{|c|}{ Neutral } & \multicolumn{2}{|r|}{$\begin{array}{l}\text { Very } \\
\text { Much } \\
\text { For }\end{array}$} & \multirow[t]{2}{*}{ Total } \\
\hline & 1 & 2 & 3 & 4 & 5 & 6 & 7 & \\
\hline $\begin{array}{l}\text { Portland } \\
\text { Metro Area }\end{array}$ & 19 & 12 & 7 & 30 & 5 & 8 & 38 & 119 \\
\hline $\begin{array}{l}\text { Eugene-Salem } \\
\text { Area } \quad\end{array}$ & 7 & 2 & 1 & 7 & 5 & 2 & 10 & 34 \\
\hline $\begin{array}{l}\text { City 10,000- } \\
50,000\end{array}$ & 4 & 1 & 1 & 4 & 3 & 0 & 21 & 34 \\
\hline Rural & 3 & 2 & 1 & 12 & 8 & 4 & 47 & 77 \\
\hline & 33 & 17 & 10 & 53 & 21 & 14 & $\overline{116}$ & 264 \\
\hline
\end{tabular}

Note: Chi Square data is included for those who may be interested. It is not discussed.

Chi Square - 38.717

Degrees of Freedom - 18

$\mathrm{P}=.0000$ (Sig. .05)
$\mathrm{N}=264$ 


\section{TABLE XIV}

ATTITUDE TOWARD HUNTING BY AGE GROUPS

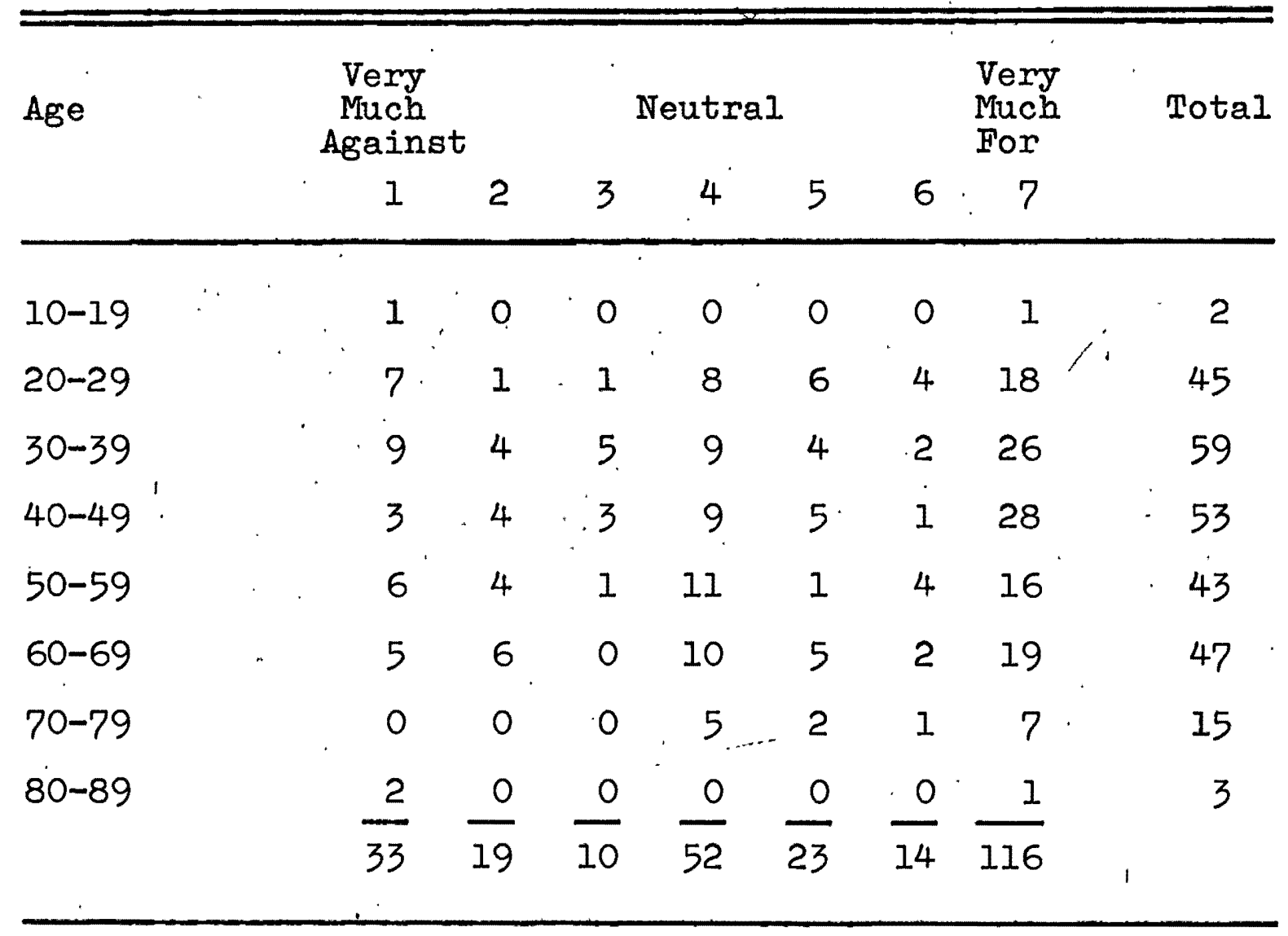

: Note: Chi Square data is included for those who may be interested. It is not discussed.

Chi Square - 55.44

Degrees of Freedom - 48 . 